\title{
Chalcolithic and Middle Bronze Age obsidian industries at Karmir Sar: A mountain view on the lithic economies of the Southern Caucasus
}

\author{
Christoph Purschwitz \\ Free University of Berlin, Institute of Near Eastern Archaeology, Fabeckstr. 23-25, 14195 Berlin, Germany. \\ Email: purschw@zedat.fu-berlin.de
}

\begin{abstract}
:
The high-altitude site of Karmir Sar is located around $2850 \mathrm{~m}$ a.s.l. on the southern slopes of Mt. Aragats (Armenia). Numerous stone structures (including vishaps, cromlechs, stone enclosures) are found all over the 40 ha-sized meadow, out of which three vishaps, four cromlechs and one circular stone structure have been investigated since 2012. According to ${ }^{14} \mathrm{C}$-dates, pottery and diagnostic lithic artefacts, human presence at Karmir Sar started as early as the Chalcolithic Period and continued (with gaps) until modern times; whereby the Middle Bronze Age (MBA) and the Medieval era represent the most intensive periods of occupation.

This contribution presents primary data on the typology and technology of 1129 chipped lithic artefacts that have been excavated in four trenches at Karmir Sar (operations KS A, KS C, KS D, and KS E). This study of the lithic industries of Karmir Sar will be embedded within the framework of lithic economy, which considers lithic artefacts as part of a comprehensive interaction between lithic production and consumption. The lithic economy includes strategies of raw material procurement, blanks production and its transformation into tools, tool use, as well as the circulation of raw materials or products. Due to multiple use episodes and a general lack of clear stratigraphical horizons, the assemblages of Karmir Sar are not suitable to define the lithic industry for specific periods (such as the Chalcolithic or MBA periods). However, the data allows for general conclusions on lithic production and consumption at Karmir Sar, which appears to be quite similar during both periods.

The Chalcolithic and MBA lithic economies at Karmir Sar are characterized by an ad hoc tool production environment, which well matches the needs of semi-mobile herder societies. The majority of raw materials appear to be procured from secondary source areas (such as riverbeds) which is indicated by a high ratio of battered and rolled surfaces. Tools are predominantly produced on-site, and according to daily demands by simple flake core technology. This allowed for a flexible, spontaneous blank and tool production without being dependent on specialized blade producers.
\end{abstract}

Keywords: chipped stone; ad hoc tool industries; Chalcolithic; Bronze Age; Armenia

Published by the School of History, Classics and Archaeology, University of Edinburgh ISSN: 2055-0472. URL: http://journals.ed.ac.uk/lithicstudies/ 


\section{Introduction: The site of Karmir Sar}

The site of Karmir Sar is located at a mean altitude of $2850 \mathrm{~m}$ a.s.l on the southern slopes of Mt. Aragats, Armenia (Figure 1) and has been investigated since 2012 by an ArmenianGerman-Italian joint project (Bobokhyan et al. 2012, 2018; Gilibert et al. 2012, 2013). Numerous stone structures have been recorded so far, including eleven prehistoric relief stelae, (the "vishaps” Karmir Sar 1 to Karmir Sar 11) and several barrows (“cromlechs”). All stone structures have been distributed across a 40-ha concave meadow, intersected by small rivulets and pools (Gilibert et al. 2012: 110-114).

Since 2013, five vishaps, four cromlechs, and a round enclosure have been excavated (Operations A, C, D, E, F and G hereafter KS A, KS C-G) (Gilibert 2017; von der Osten et al., 2017; Hnila et al., in press). KS A comprises the excavation of four cromlechs (no. 1-4), out of which one (cromlech no. 1) includes a vishap in secondary position (Figure 2). KS C and KS D were opened around collapsed vishaps, both of which were found in horizontal positions covering their original foundation pits (Figures 3 and 4). KS F and G were opened around two further collapsed vishaps, both secondarily removed from their original standing spot, which remains unidentified. KS E is a circular stone feature provisionally interpreted as a medieval animal corral (von der Osten et al. 2017; Hnila et al., in press).

Vishaps (Arm. "dragons") are a unique class of stelae with animal reliefs found distributed across the southern Caucasus. So far, approx. 120 vishaps have been recorded in the territories of modern Armenia, Georgia and Turkey (Bobokhyan et al. 2012: 7; Gilibert et al. 2013: fig. 2). Usually, vishaps are found in meadows at altitudes of between 2000 and $3000 \mathrm{~m}$ a.s.l., often in the vicinity of small rivulets and pools. They occur isolated or in clusters and are sometimes secondarily embedded in cromlechs (Bobokhyan et al. 2012: 8; Gilibert et al. 2013: 200). In the view of the excavators at Karmir Sar, vishaps are connected with transhumant pastoralists, which used the highland meadows as summer pastures (e.g., Gilibert et al. 2012: 119; cf. also Kushnareva 1997: 192-196).

The period of vishap erection is still not clear, since most vishaps are found out of their original context of construction ( $c$. contributions in Petrosyan \& Bobokhyan 2015 [eds.]). Associated artefacts and typological considerations may point to a Middle Bronze Age date (2200-1600 BCE) (cf. Gilibert 2015; Gilibert et al. 2012: 114-117; Bobokhyan et al. 2012: 7), although the stratigraphic relation between vishaps and cromlechs, barrows or stone platforms is often not clear (Bobokhyan et al., 2018). A charcoal (MAMS 25322) from the fill of the burial chamber of cromlech no. 4 (KS A) provided a late 3rd millennium date (2198-2036 cal. BCE, 95.4\%) which well corresponds to ceramics of the early Trialeti-Vanadzor-tradition (c. 2200-2000 BCE) that were found in the same context. Furthermore, a pottery sherd from KS C provided an OSL-age estimate of $3590 \pm 320$ (1895-1255 BCE), and (although stratigraphically not connected to the vishap) attests to an intensive human presence during the Middle Bronze Age (MBA) period at Karmir Sar. Conversely, the ${ }^{14} \mathrm{C}$-sample RTD 8866 from a pit at the centre of cromlech No. 1 in KS A (not a burial chamber), dated 5215-5035 cal. BCE, 95.4\%; a charcoal from a pit in KS C dated 4070-3970 cal. BCE, 85.8\%; the charcoal RTD 8868 from the vishap foundation pit in KS D dated 4265-4040 cal. BCE, 91.1\%. These datings provide evidence of human presence at Karmir Sar in the Chalcolithic period and open up the possibility that the vishaps also date to this period.

More than 1100 obsidian artefacts have been found during the 2013-2016 excavation campaigns at Karmir Sar, distributed over all the excavated contexts. Their occurrence below, upon and between the stone structures indicates that many of them may not be connected to the construction periods of the structures themselves and suggests the presence of multiple use episodes. 


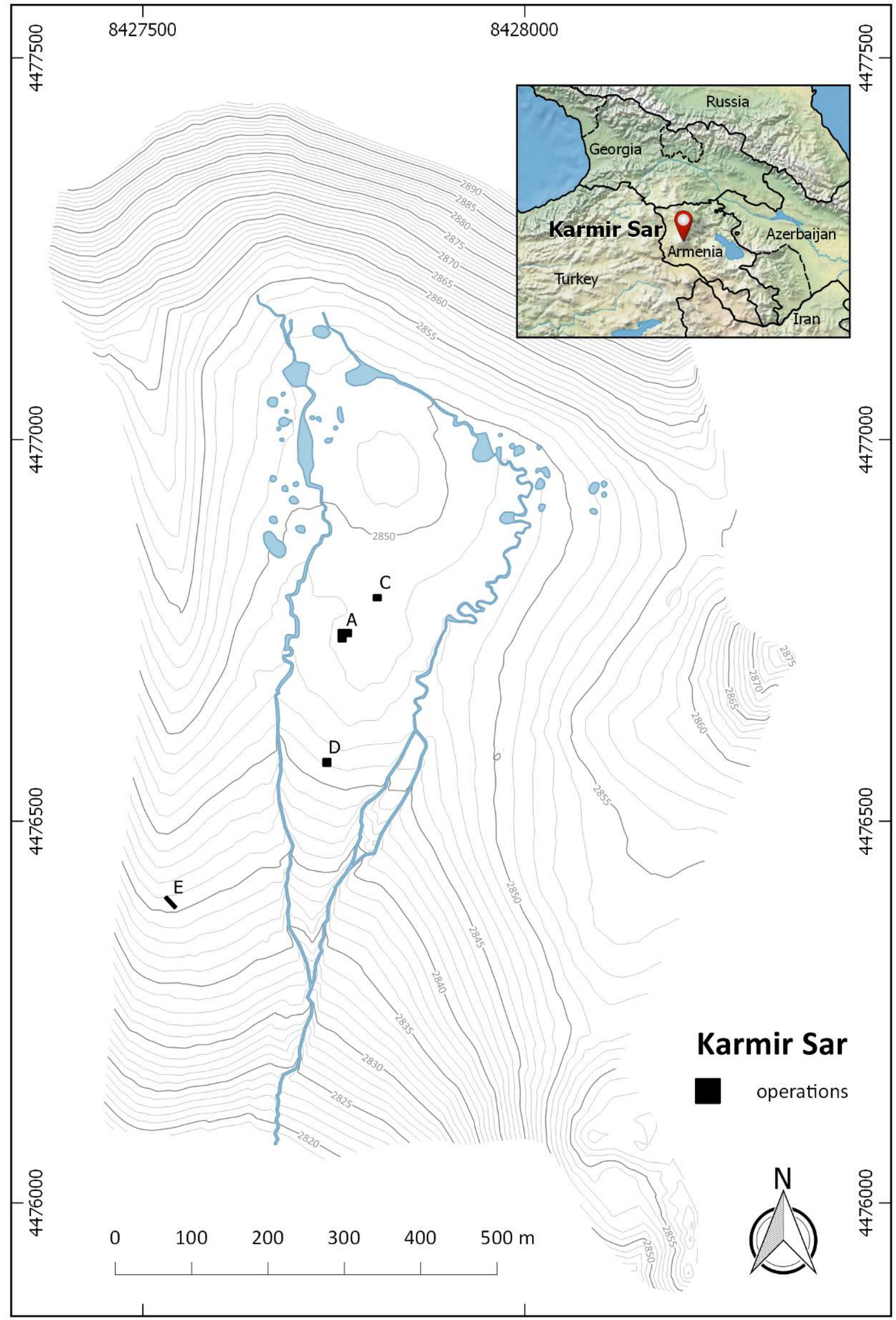

Figure 1. The site of Karmir Sar (map by P. Hnila. Topographical data by S. Davtyan and Natural Earth. Projection: Pulkovo42/Gauss-Kruger Zone 8). 


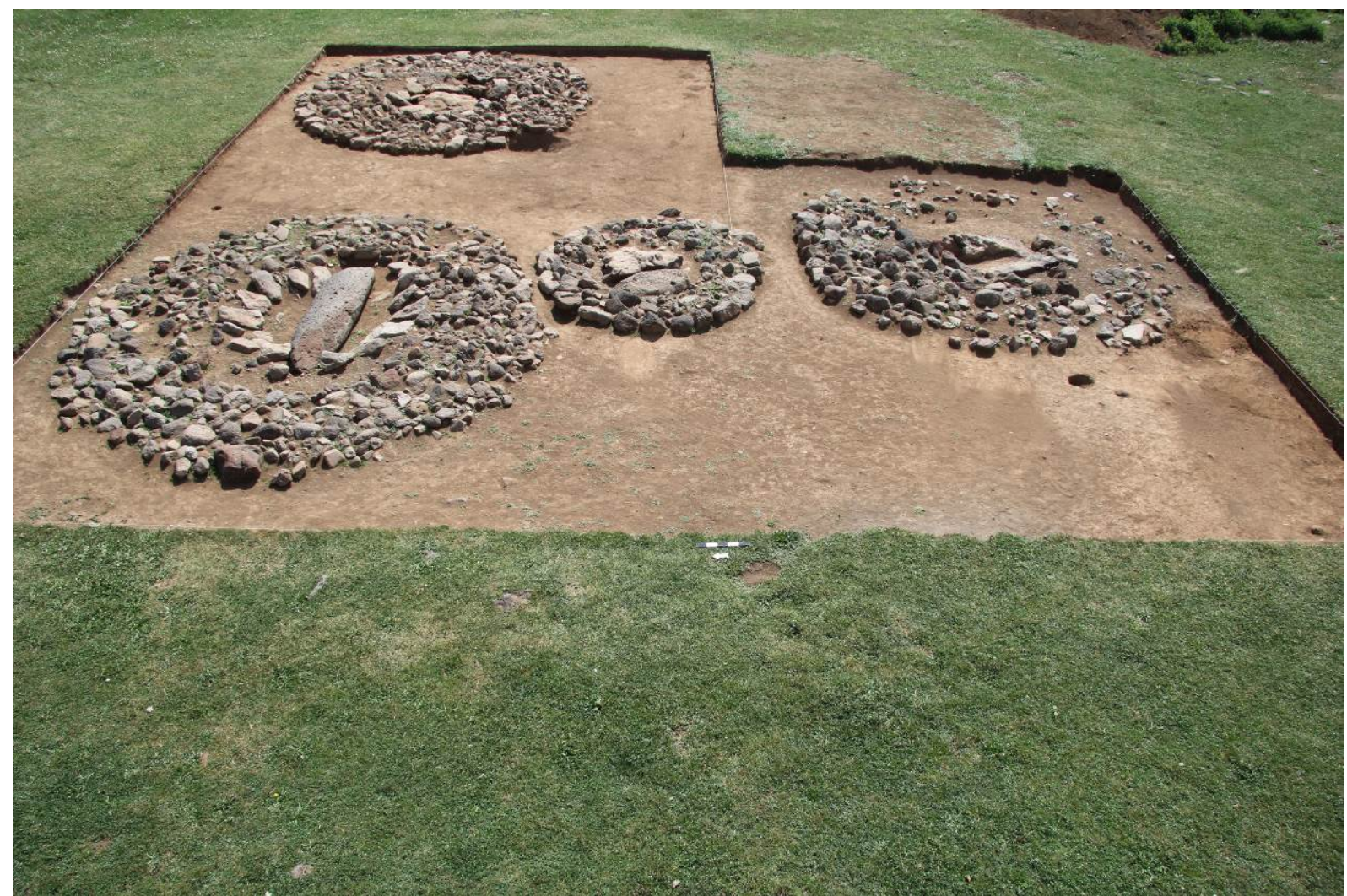

Figure 2. Cromlechs with re-used vishap (left) in KS A, facing East (photo by P. Hnila).

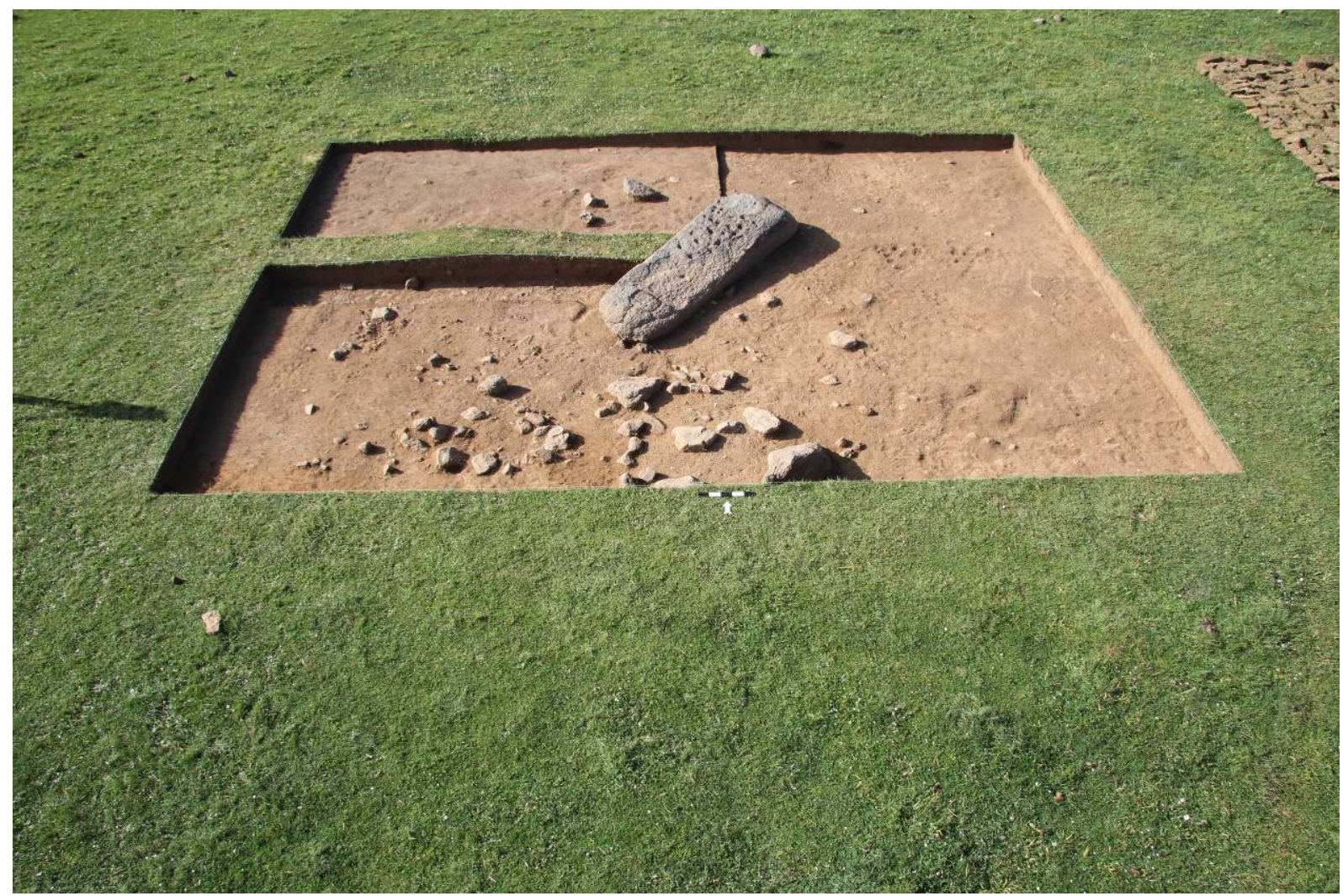

Figure 3. Fallen vishap covering its former construction pit in KS C, facing North. Note the secondary "cups” on the upper face (photo by P. Hnila). 


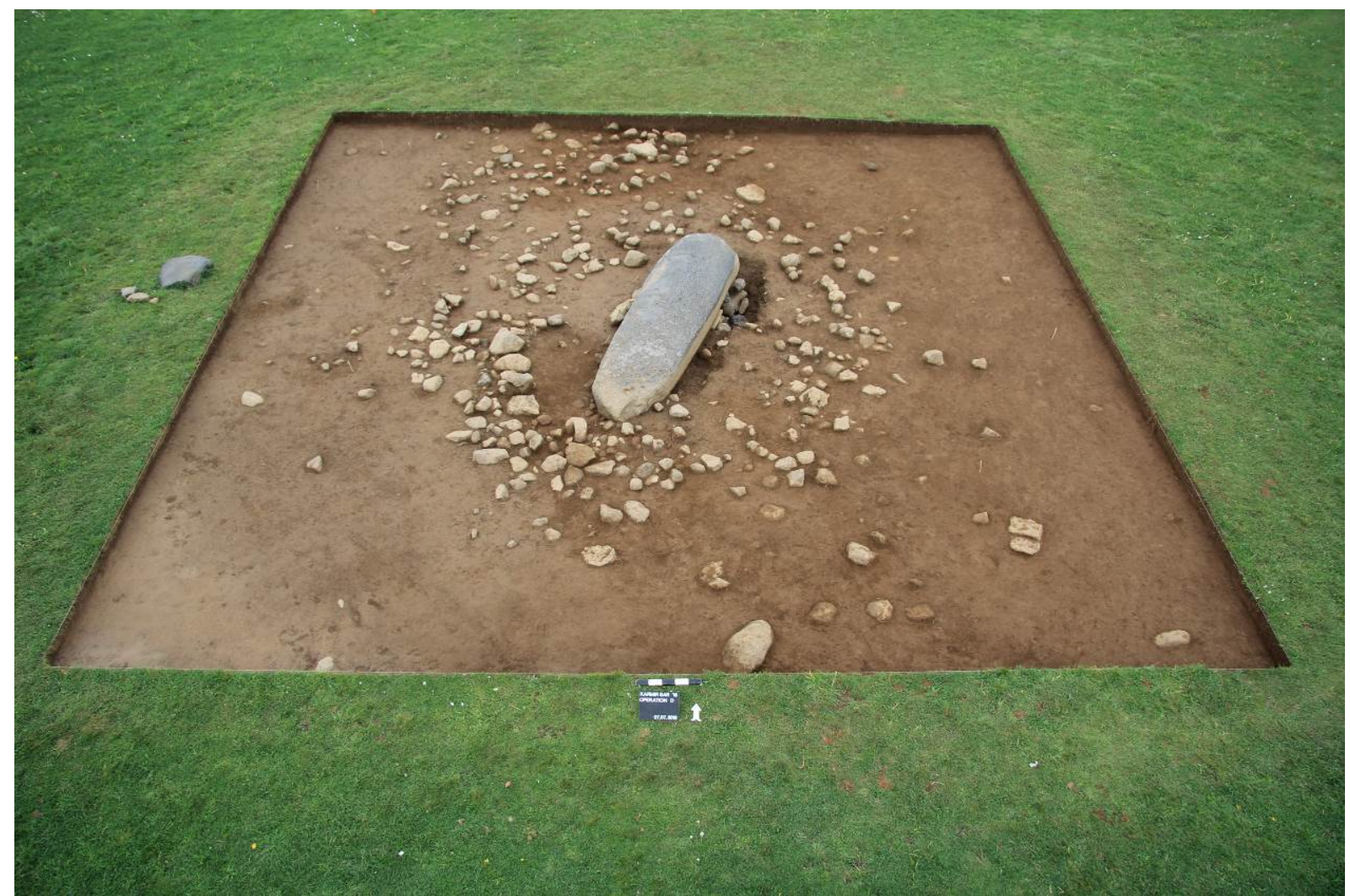

Figure 4. Fallen vishap covering its former construction pit in KS D, facing North (photo by P. Hnila).

\section{Post-Stone-Age lithic industries in the southern Caucasus - a neglected field of research}

Though an increasing number of lithic studies have been published in the last years, only a few of them concern the Chalcolithic or later periods (cf. Gasparyan \& Arimura 2014 [eds.]; Chataigner et al. 2014). Particularly, the expedient Bronze Age industries of the Caucasus are poorly defined because typological or technological studies are totally missing. If Bronze Age lithics are of concern in publications, the presented data is often restricted to obsidian provenience analyses or to the illustration of some fossiles directeurs (such as arrowheads or sickle implements, e.g., Badalyan \& Avetisyan 2007; Chataigner \& Gratuze 2014; Simonyan 2015). However, in the southern Caucasus there appears to be a common association between chipped lithic artefacts and Bronze to Iron Age sites, such as kurgans, cromlechs, or stone barrows (cf. Badalyan \& Avetisyan 2007; Muradyan 2014: footnote 4; cf. also Chataigner \& Gratuze 2014). Although never systematically studied, this association strongly suggests the continuation and importance of lithic practice and tool production far beyond the Stone Ages.

The continuity of lithic technologies in the post-Stone-Age-periods is well attested in adjacent regions (such as Anatolia, Mesopotamia, or the Levant, e.g., Greenfields 2013; Hartenberger et al. 2014; Kobayashi 2007; Nishiaki 2014; Rosen 1997; Rosen \& Vardi 2014; Sagona et al. 1998; Steadman et al. 2013), where lithic tool production and use persisted until the Late Bronze Age period and in some areas even beyond.

This contribution aims at shedding some light on the South-Caucasian Chalcolithic and MBA obsidian industries based on the lithic artefacts found by the Armenian-German-Italian mission at Karmir Sar. More than 1100 chipped lithic artefacts that were found in four excavation areas (KS A, KS C, KS D, and KS E) will be presented in a typo-technological study. This study will be embedded within the framework of lithic economy, which considers lithic artefacts as part of a comprehensive interaction between lithic production and consumption. The lithic economy includes (among others): the modes and strategies of raw 
material procurement, the production of blanks and their transformation into tools, tool use, as well as the circulation of raw materials or products (cf. Purschwitz 2017, in press).

\section{The chipped lithic economy}

\subsection{Methods and samples}

The samples from the investigation include the chipped lithic artefacts of four excavation areas (KS A, KS C, KS D, and KS E). In total 1129 lithic artefacts were analysed. The sediment was not sifted - all artefacts visible by the naked eye were collected. Each lithic artefact underwent a comprehensive documentation in which typology, technological attributes, and raw material features were recorded. Tools were classified according to morpho-typological tool types. In addition, ad hoc tools or pieces with irregular edge splinterings (e.g., splintered pieces) were checked for microscopic use wears (magnification 40 to $330 x)$.

\subsection{Raw materials and raw material procurement}

The raw materials consist almost entirely of obsidian. Only eight out of 1,129 artefacts were made of other materials - such as chert $(n=6)$ or volcanic rock $(n=2)$.

The obsidian artefacts were classified macroscopically according to colour, translucency and texture, into nine raw material groups (hereafter RM1 to RM 9, Table 1). Additionally, RM 19 was established for unidentified or unidentifiable items. 285 artefacts from the total sample ( 25\%) were analysed with a portable XRF (personal communication with Hnila on 14 February 2018).

Table 1. Macroscopic raw material classification for obsidians.

\begin{tabular}{|c|c|c|c|}
\hline $\begin{array}{l}\text { Raw } \\
\text { material }\end{array}$ & Colour & Translucency & Texture \\
\hline RM 1 & None & Completely transparent & extra fine \\
\hline RM 2 & Grey to black & Transparent & extra fine \\
\hline RM 3 & Black & Completely opaque & very fine \\
\hline RM 4 & Black & $\begin{array}{l}\text { Opaque and transparent alternating } \\
\text { bands or patches }\end{array}$ & $\begin{array}{l}\text { very fine to extra } \\
\text { fine }\end{array}$ \\
\hline RM 5 & Grey & Completely opaque & very fine \\
\hline RM 6 & Grey & Completely opaque & medium \\
\hline RM 7 & Black orange mottled & Completely opaque & very fine \\
\hline RM 8 & Black orange mottled & Opaque with transparent patches & very fine \\
\hline RM 9 & Black red mottled & Opaque with transparent patches & very fine \\
\hline
\end{tabular}

It is important to note that macroscopic raw material classifications of obsidians are not suitable for source identification in the Caucasus region (cf. Chataigner \& Gratuze 2014; Frahm 2010; Frahm et al. 2014). However, a macroscopic raw material analysis provides general information on the nature of used source areas, and therefore is a helpful tool in investigating human procurement behaviour - if geochemical provenance analysis is not applicable or only can be applied for minor parts of the assemblage. 
Table 2. Breakdown of raw materials (RM) according to numbers and weight. Abbreviations: undet. - undetermined.

\begin{tabular}{|c|c|c|c|c|c|c|c|c|c|c|c|c|c|c|c|c|}
\hline & \multicolumn{4}{|c|}{$K S A$} & \multicolumn{4}{|c|}{$K S C$} & \multicolumn{4}{|c|}{$K S D$} & \multicolumn{4}{|c|}{$K S E$} \\
\hline & Count & $\%$ & Weight (g) & $\%$ & Count & $\%$ & Weight (g) & $\%$ & Count & $\%$ & Weight (g) & $\%$ & Count & $\%$ & Weight (g) & $\%$ \\
\hline \multicolumn{17}{|l|}{ Obsidian } \\
\hline RM 1 & 313 & 63.0 & 399.3 & 45.6 & 160 & 43.1 & 244.7 & 32.4 & 81 & 34.5 & 62.5 & 16.2 & 9 & 34.6 & 10.2 & 42.1 \\
\hline RM 2 & 51 & 10.3 & 161.6 & 18.4 & 52 & 14.0 & 98.1 & 13.0 & 45 & 19.1 & 82.1 & 21.2 & 4 & 15.4 & 3.2 & 13.2 \\
\hline RM 3 & 41 & 8.2 & 118.5 & 13.5 & 72 & 19.4 & 211.8 & 28.0 & 58 & 24.7 & 152.1 & 39.3 & 6 & 23.1 & 7.3 & 30.2 \\
\hline RM 4 & 64 & 12.9 & 146.2 & 16.7 & 37 & 10.0 & 54.5 & 7.2 & 16 & 6.8 & 19.7 & 5.1 & 5 & 19.2 & 1.1 & 4.5 \\
\hline RM 5 & 4 & 0.8 & 1.9 & 0.2 & 20 & 5.4 & 38.6 & 5.1 & 11 & 4.7 & 16.3 & 4.2 & 2 & 7.7 & 2.2 & 9.1 \\
\hline RM 6 & 2 & 0.4 & 9.1 & 1.0 & 6 & 1.6 & 22.0 & 2.9 & & & & & & & & \\
\hline RM 7 & & & & & 1 & 0.3 & 1.7 & 0.2 & 8 & 3.4 & 29.4 & 7.6 & & & & \\
\hline RM 8 & & & & & 3 & 0.8 & 3.8 & 0.5 & & & & & & & & \\
\hline RM 9 & 12 & 2.4 & 23.0 & 2.6 & & & & & 1 & 0.4 & 6.0 & 1.6 & & & & \\
\hline $\begin{array}{l}\text { RM } 19 \\
\text { (undet.) }\end{array}$ & 7 & 1.4 & 9.3 & 1.1 & 17 & 4.6 & 11.6 & 1.5 & 13 & 5.5 & 15.8 & 4.1 & & & & \\
\hline Chert & 2 & 0.4 & 7.4 & 0.8 & 2 & 0.5 & 65.0 & 8.6 & 2 & 0.9 & 2.9 & 0.8 & & & & \\
\hline $\begin{array}{l}\text { Volcanic } \\
\text { rock }\end{array}$ & 1 & 0.2 & 0.2 & $<0.1$ & 1 & 0.3 & 4.6 & 0.6 & & & & & & & & \\
\hline Total & 497 & 100 & 876.5 & 100 & 371 & 100 & 756.4 & 100 & 235 & 100 & 386.8 & 100 & 26 & 100 & 24.2 & 100 \\
\hline
\end{tabular}


The RMs are dominated by transparent obsidians (RM1 and RM2) which comprise $50.0 \%$ to $73.3 \%$ of the samples. Opaque obsidians (RM 3, 5, 6) consist of $9.4 \%$ to $30.8 \%$. A third very common group is RM 4 (mixed translucent and black opaque obsidians $-6.8 \%$ to $19.2 \%$ ) - which once more stresses the limitations of a mere macroscopic raw material approach, as transparent and opaque obsidians can occur in the same source. Coloured obsidians (RM 7, 8, 9) are rare and account for less than 3.4\% of the samples (Table 2).

The RM distribution among the samples of KS C, KS D, and KS E is very similar. Most frequent are RM 1 (34.6\% to 43.1\%), followed by RM 2 and RM 3, each of which are represented by between 14.0 and $24.7 \%$. RM 5 is also very common and accounts for around $5 \%$.

KS A however, differs clearly with a much higher proportion of RM 1 (63.0\%), lower numbers of RM 3 (8.2\%) and the almost complete absence of RM 5 (0.8\%).

The vast majority (84\%) of the 285 obsidians that underwent a geochemical provenience analysis with pXRF can be attributed to the Arteni, Gutansar, and Hatis volcanic complexes which are accessible throughout the year. In contrast, obsidians of the Tsakhunyats and Gegham volcanic complexes are rarely found at Karmir Sar (personal communication with Hnila on 14 February 2018). Their outcrops are situated in high altitudes and are assumed to be only seasonally accessible in the summer period due to topography and snow cover (e.g., Badalyan et al. 2004a; Barge \& Chataigner 2003).

However, the geochemical source identification from a limited sample is not sufficient for the comprehensive reconstruction of involved raw material procurement behaviour. Due to erosion and weathering processes, smaller and larger blocks of obsidian can be transported by rivers or wadis over considerable distances. Obsidian raw material often can be collected from riverine deposits under much easier conditions than at their mountainous volcanic primary sources - although the knapping quality may diminish dramatically the longer the material is transported.

The analysis of surfaces has therefore shown to be a useful approach in investigating the relation between secondary and primary (or close-by primary) sources of lithic economies (Purschwitz 2017, in press). Obsidian weathering (hydration) rinds develop continually on the exposed surfaces (e.g., Braswell 1996). At primary outcrops, the hydration rind is regular and usually devoid of battering or abrasion. At riverine deposits in contrast, the surfaces often are battered, abraded, or rolled due to fluvial impact and extensive transportation.

At Karmir Sar the obsidians are overwhelmingly characterized by heavily battered and rolled surfaces, which account for $58.5 \%$ to $66.7 \%$ of each sample (Table 3 ). This points to secondary source areas, and the majority of the Karmir Sar obsidian appears to be procured from riverbeds or riverine deposits. We assume that the herders of Karmir Sar extracted obsidian raw material directly from rivers of the Ararat plain. They may have collected the raw material while they were watering their stock as they occupied the lower plains during autumn and spring (sensu embedded procurement).

However, other procurement strategies, such as raw material expeditions or indirect procurement modes (exchange) may have occurred as well, although they contributed in a smaller way to the obsidian raw material supply. At present there are few indicators for exchange. The bladelet and blade tools (including those of chert) may have involved exchange, as there is no evidence of on-site production of blades or bladelets, and based on the available data, blades or bladelets most likely arrived Karmir Sar as tool implements or finished tools. An isolated pressure retouched projectile point found at KS E might be exchanged, as there is no other evidence of this particular retouch technique within the comprehensive Karmir Sar tool kit. Moreover, some obsidian from the Tsakhunyats and Gegham volcanic complexes might be involved in exchange as well. This is indicated by the restricted seasonal access of both outcrops during a few summer months (cf. Badalyan et al. 
2004a; Barge \& Chataigner 2003), which is also considered the most likely occupation season of Karmir Sar.

Table 3. Surface features of the Karmir Sar obsidian industry.

\begin{tabular}{l|cc|cc|cc|cc|cc}
\hline & \multicolumn{2}{|c|}{ KS A } & \multicolumn{2}{|c|}{ KS C } & \multicolumn{2}{c|}{ KS D } & \multicolumn{2}{|c|}{ KS E } & \multicolumn{2}{|c}{ Total } \\
& $\mathrm{n}$ & $\%$ & $\mathrm{n}$ & $\%$ & $\mathrm{n}$ & $\%$ & $\mathrm{n}$ & $\%$ & $\mathrm{n}$ & $\%$ \\
\hline Weathering rinds & 35 & & 17 & & 9 & & 1 & & 62 & \\
\hline Total 'Primary Source' Surfaces & $\mathbf{3 5}$ & $\mathbf{3 8 . 0}$ & $\mathbf{1 7}$ & $\mathbf{4 1 . 5}$ & $\mathbf{9}$ & $\mathbf{3 6 . 0}$ & $\mathbf{1}$ & $\mathbf{3 3 . 3}$ & $\mathbf{6 2}$ & $\mathbf{3 8 . 5}$ \\
\hline Battered or rolled surfaces & 48 & & 14 & & 9 & & 1 & & 72 \\
Patination & 4 & & 3 & & 3 & & 1 & & 11 \\
Old fractures with patination & 2 & & 2 & & 1 & & & & 5 \\
Patinated battered \& rolled & 3 & & 5 & & 3 & & & & 11 \\
$\quad$ surfaces & & & & & & & & & & \\
\hline Total Secondary Surfaces & $\mathbf{5 7}$ & $\mathbf{6 2 . 0}$ & $\mathbf{2 4}$ & $\mathbf{5 8 . 5}$ & $\mathbf{1 6}$ & $\mathbf{6 4 . 0}$ & $\mathbf{2}$ & $\mathbf{6 6 . 7}$ & $\mathbf{9 9}$ & $\mathbf{6 1 . 5}$ \\
\hline Total & $\mathbf{9 2}$ & $\mathbf{1 0 0}$ & $\mathbf{4 1}$ & $\mathbf{1 0 0}$ & $\mathbf{2 5}$ & $\mathbf{1 0 0}$ & $\mathbf{3}$ & $\mathbf{1 0 0}$ & $\mathbf{1 6 1}$ & $\mathbf{1 0 0}$ \\
Undetermined & 4 & & 3 & & 5 & & & & 13 \\
\hline
\end{tabular}

\subsection{Lithic production at Karmir Sar}

\subsubsection{Primary production}

The primary products are composed of a high number of microdebris - such as debris, flakelets, or chips - which altogether form more than $75 \%$ of the samples (Table 4). The second most prominent category is flakes (13.9\%) - followed by cores (2.1\%), while blades (1.5\%) and bladelets (1.2\%), core trimming elements (hereafter CTE, 1.2\%), and primary elements $(1.0 \%)$ are rather rare.

24 cores were found, all of which are flake cores and most of which have been completely exhausted. Two types of flake cores occur, from which irregular flake cores $(n=10)$ and single platform flake cores $(n=8)$ are equally represented. Exhausted cores or core fragments are represented by six items.

Primary elements (flakes with at least 30\% dorsal surface cover and less than three dorsal negatives) comprise 12 pieces, and CTE were found in 14 items. All CTE were derived from flake core reduction. Among them are four core tablets, four overshoots, and two clean-up flakes.

Blades and bladelets have been found in more than 30 medial segments, out of which all were modified into tools.

There are some differences in the composition of primary product classes between the samples of KS A, KS C and KS D. These comprise a higher number in cores and CTE, both at KS C and KS D, while debris is represented in lower amounts than at KS A. However, the most significant difference is the presence of numerous blade and bladelet segments at KS C and KS D, which are very rare at KS A, and missing completely at KS E.

\subsubsection{Technology, skill and reduction sequence}

The obsidian finds are almost exclusively based on simple flake technology. Flakes and flakelets were knapped from simple flake cores, often until the cores were completely exhausted. All major stages of flake core reduction are attested. The abundance of microdebris clearly suggests on-site knapping and core reduction at Karmir Sar (cf. Quintero 2010: 116-117; Schiffer 1987: 62-64). However, the rare presence of primary elements and CTE, indicates that the raw material arrived Karmir Sar mainly as already established, and 
partly reduced cores. Suitable flakes (and to a lesser amount flakelets) were selected and used as tool blanks.

Table 4. Breakdown of primary products at Karmir Sar. Abbreviations: undet. - undetermined.

\begin{tabular}{|c|c|c|c|c|c|c|c|c|c|c|}
\hline & \multicolumn{2}{|c|}{ KS A } & \multicolumn{2}{|c|}{ KS C } & \multicolumn{2}{|c|}{ KS D } & \multicolumn{2}{|c|}{ KS E } & \multicolumn{2}{|c|}{ Total } \\
\hline & $\mathrm{n}$ & $\%$ & $\mathrm{n}$ & $\%$ & $\mathrm{n}$ & $\%$ & $\mathrm{n}$ & $\%$ & $\mathrm{n}$ & $\%$ \\
\hline Chunks & & & & & & & & & & \\
\hline Cores & 8 & 1.6 & 10 & 2.7 & 6 & 2.6 & & & 24 & 2.1 \\
\hline - Flake cores & 8 & 1.6 & 5 & 1.3 & 5 & 2.1 & & & 18 & 1.6 \\
\hline $\begin{array}{l}\text { - Blade cores } \\
\text { - Bladelet cores }\end{array}$ & & & & & & & & & & \\
\hline - Exhausted or indet. cores & & & 5 & 1.3 & 1 & 0.5 & & & 6 & 0.5 \\
\hline Core trimming elements & 3 & 0.6 & 7 & 1.9 & 4 & 1.7 & & & 14 & 1.2 \\
\hline Primary elements & 7 & 1.4 & 3 & 0.8 & 2 & 0.9 & & & 12 & 1.1 \\
\hline Debris & 198 & 39.8 & 126 & 34.0 & 92 & 39.1 & 8 & 30.8 & 424 & 37.6 \\
\hline Chips & 45 & 9.1 & 25 & 6.7 & 20 & 8.5 & 3 & 11.5 & 93 & 8.2 \\
\hline Flakelets & 146 & 29.4 & 111 & 29.9 & 77 & 32.8 & 9 & 34.6 & 343 & 30.4 \\
\hline Flakes & 77 & 15.5 & 54 & 14.6 & 20 & 8.5 & 4 & 15.4 & 155 & 13.7 \\
\hline Blades & 3 & 0.6 & 6 & 1.6 & 6 & 2.6 & & & 15 & 1.3 \\
\hline - Blades (pressure) & & & 2 & 0.5 & 4 & 1.7 & & & 6 & 0.5 \\
\hline - Blades (percussion) & 3 & 0.6 & 3 & 0.8 & & & & & 6 & 0.5 \\
\hline - Indetermined blades & & & 1 & 0.3 & 2 & 0.9 & & & 3 & 0.3 \\
\hline Bladelets & 1 & 0.1 & 10 & 2.7 & 3 & 1.3 & & & 14 & 1.2 \\
\hline - Bladelets (pressure) & & & 5 & 1.3 & 3 & 1.3 & & & 8 & 0.7 \\
\hline $\begin{array}{l}\text { - Bladelets (percussion) } \\
\text { - Indetermined bladelets }\end{array}$ & 1 & 0.1 & 5 & 1.3 & & & & & 6 & 0.5 \\
\hline Burin spalls & 1 & 0.1 & 1 & 0.3 & 1 & 0.5 & & & 3 & 0.3 \\
\hline Undet. primary products & 8 & 0.8 & 18 & 4.9 & 4 & 1.7 & 2 & 7.7 & 32 & 2.8 \\
\hline Total & 497 & 100 & 371 & 100 & 235 & 100 & 26 & 100 & 1129 & 100 \\
\hline Tools & 100 & 20.1 & 112 & 30.2 & 72 & 30.6 & 11 & 42.3 & 295 & 26.1 \\
\hline
\end{tabular}

The knapping skills needed for flake production and the modification of flakes or flakelets into tools are simple, and can be seen as basic lithic knowledge in many prehistoric societies. At Karmir Sar a very restricted set of knapping techniques was applied. The knapping scars of the Karmir Sar flake industry clearly show typical features of direct hard hammer percussion (such as pronounced bulbs, knapping scars, or riddles, Table 5). Platforms are predominantly plain or cortical, and platform preparation was rarely applied (Table 5). The flake core reduction was opportunistic without showing major efforts of core preparation or platform maintenance.

Except for the quantity of knapping errors, there are hardly any meaningful differences among the samples. Generally, the skill level at Karmir Sar was low, and may reflect a discontinuous, sporadic use of lithic technology. This is indicated by a very low degree of platform preparation, a common use of cortical parts as platforms (Table 5), and by a very high number of knapping accidents (i.e. step or hinge fractures, plunging flakes). $21.5 \%$ of all flake products with preserved distal part are characterized by such errors (Table 6). Negatives of supposed knapping errors are also visible on cores, or on the dorsal parts of flakes and flakelets. Interestingly, there is considerable variation between the samples of KS A (error rate $18.6 \%)$ and KS C (31.7\%) or KS D (33.3\%). It appears that the average skill level of 
knappers practiced at KS A was higher than those of KS C and D - an interpretation that is in accordance with the density and quantity of knapping products (which is highest at KS A).

Table 5. Knapping features and platform morphology of flakes.

\begin{tabular}{|c|c|c|c|c|c|c|c|c|}
\hline & \multicolumn{2}{|c|}{ KS A } & \multicolumn{2}{|c|}{ KS C } & \multicolumn{2}{|c|}{ KS D } & \multicolumn{2}{|c|}{ Total } \\
\hline Knapping features & \multicolumn{2}{|c|}{$n=52$} & \multicolumn{2}{|c|}{$n=23$} & \multicolumn{2}{|c|}{$n=9$} & \multicolumn{2}{|c|}{$n=84$} \\
\hline Bulb - very pronounced & 10 & $19.2 \%$ & 5 & $21.7 \%$ & 2 & $22.2 \%$ & 17 & $20.2 \%$ \\
\hline Bulb - pronounced & 23 & $44.2 \%$ & 11 & $47.8 \%$ & 5 & $55.5 \%$ & 39 & $46.4 \%$ \\
\hline Bulb - diffuse & 14 & $26.9 \%$ & 7 & $30.4 \%$ & 2 & $22.2 \%$ & 23 & $27.4 \%$ \\
\hline Bulb - indetermined & 5 & $9.6 \%$ & & & & & 5 & $6.0 \%$ \\
\hline Lipping (present) & 11 & $21.1 \%$ & 7 & $30.4 \%$ & 6 & $66.7 \%$ & 24 & $28.6 \%$ \\
\hline Scar (present) & 28 & $53.8 \%$ & 14 & $60.9 \%$ & 2 & $22.2 \%$ & 44 & $52.4 \%$ \\
\hline Riddles (present) & 30 & $57.8 \%$ & 14 & $60.9 \%$ & 5 & $55.5 \%$ & 49 & $58.3 \%$ \\
\hline Platform preparation & \multicolumn{2}{|c|}{$n=50$} & \multicolumn{2}{|c|}{$\mathrm{n}=\mathbf{2 0}$} & \multicolumn{2}{|r|}{$n=9$} & \multicolumn{2}{|c|}{$n=79$} \\
\hline Unprepared & 37 & $74.0 \%$ & 14 & $70.0 \%$ & 6 & $66.7 \%$ & 57 & $72.2 \%$ \\
\hline Coarse chipping & 9 & $18.0 \%$ & 4 & $20.0 \%$ & & & 13 & $16.5 \%$ \\
\hline Microchipping & 1 & $2.0 \%$ & 1 & $5.0 \%$ & 1 & $11.1 \%$ & 3 & $4.0 \%$ \\
\hline $\begin{array}{l}\text { Microchipping \& grinding } \\
\text { Grinding }\end{array}$ & & & & & 1 & $11.1 \%$ & 1 & $1.3 \%$ \\
\hline Indetermined & 3 & $6.0 \%$ & 1 & $5.0 \%$ & 1 & $11.1 \%$ & 5 & $6.3 \%$ \\
\hline Platform morphology & \multicolumn{2}{|c|}{$n=51$} & \multicolumn{2}{|c|}{$n=20$} & \multicolumn{2}{|r|}{$n=9$} & \multicolumn{2}{|c|}{$n=80$} \\
\hline Cortical or natural & 12 & $23.5 \%$ & 3 & $15.0 \%$ & & & 15 & $18.6 \%$ \\
\hline Plan & 23 & $45.1 \%$ & 8 & $40.0 \%$ & 6 & $66.7 \%$ & 37 & $46.3 \%$ \\
\hline Dihedral & 1 & $2.0 \%$ & 2 & $10.0 \%$ & 1 & $11.1 \%$ & 4 & $5.0 \%$ \\
\hline Facetted & 5 & $9.8 \%$ & 2 & $10.0 \%$ & 2 & $22.2 \%$ & 9 & $11.3 \%$ \\
\hline Crushed & 4 & $7.8 \%$ & 1 & $5.0 \%$ & & & 5 & $6.3 \%$ \\
\hline \multicolumn{9}{|l|}{ Unihedral } \\
\hline Ridged & & & & & & & & \\
\hline Atypical & 5 & $9.8 \%$ & 3 & $15.0 \%$ & & & 8 & $10.0 \%$ \\
\hline Indetermined & 1 & $2.0 \%$ & 1 & $5.0 \%$ & & & 2 & $2.5 \%$ \\
\hline Platform shape & \multicolumn{2}{|c|}{$n=51$} & \multicolumn{2}{|c|}{$n=19$} & & $n=9$ & \multicolumn{2}{|c|}{$n=79$} \\
\hline Linear & 1 & $2.0 \%$ & 1 & $5.3 \%$ & & & 2 & $2.5 \%$ \\
\hline Triangular & 16 & $31.4 \%$ & 5 & $26.3 \%$ & 4 & $44.4 \%$ & 25 & $31.6 \%$ \\
\hline Trapezoidal & 9 & $17.6 \%$ & 3 & $15.8 \%$ & 1 & $11.1 \%$ & 13 & $16.5 \%$ \\
\hline Rectangular & 3 & $5.9 \%$ & 2 & $10.5 \%$ & 2 & $22.2 \%$ & 7 & $8.9 \%$ \\
\hline Rhomboidal & 2 & $3.9 \%$ & 2 & $10.5 \%$ & & & 4 & $5.1 \%$ \\
\hline Lenticular & 11 & $21.6 \%$ & 4 & $21.1 \%$ & 1 & $11.1 \%$ & 16 & $20.3 \%$ \\
\hline Punctiform & & & & & & & & \\
\hline 'Chapeau de gendarme' & 1 & $2.0 \%$ & & & & & 1 & $1.3 \%$ \\
\hline 'En aile d'oiseau' & 3 & $5.9 \%$ & 1 & $5.3 \%$ & 1 & $11.1 \%$ & 5 & $6.3 \%$ \\
\hline Indetermined & 5 & $9.8 \%$ & 1 & $5.3 \%$ & & & 6 & $7.6 \%$ \\
\hline
\end{tabular}

There is no evidence of on-site blade or bladelet production at Karmir Sar. All obsidian blades and bladelets are medial segments. All of them are retouched or show traces of tool use. As neither production waste nor tool production waste was found, it is reasonable to conclude that medial blade or bladelet segments probably arrived Karmir Sar as tools or 
already retouched implements. Nevertheless, the dorsal scar pattern of blade-bladelets shows that both percussion and pressure technique was applied during the core reduction.

Table 6. Morphology of flake terminations. Abbreviations: * Presumed knapping errors.

\begin{tabular}{|c|c|c|c|c|c|c|c|c|}
\hline & \multicolumn{2}{|c|}{$\begin{array}{l}\text { KS A } \\
n=54\end{array}$} & \multicolumn{2}{|c|}{$\begin{array}{l}\text { KS C } \\
n=41\end{array}$} & \multicolumn{2}{|r|}{$\begin{array}{l}\text { KS D } \\
n=12\end{array}$} & \multicolumn{2}{|c|}{$\begin{array}{c}\text { Total } \\
n=107\end{array}$} \\
\hline Hinged* & 6 & $11.1 \%$ & 12 & $29.3 \%$ & 3 & $25.0 \%$ & 17 & $15.9 \%$ \\
\hline Step-fracture* & 1 & $1.9 \%$ & & & & & 1 & $0.9 \%$ \\
\hline Rippled relief & 4 & $7.4 \%$ & & & & & 4 & $3.7 \%$ \\
\hline Straight 'feathered' & 40 & $74.1 \%$ & 28 & $68.3 \%$ & 8 & $66.7 \%$ & 76 & $71.0 \%$ \\
\hline Plunged ('overshoot')* & 3 & $5.6 \%$ & 1 & $2.4 \%$ & 1 & $8.3 \%$ & 5 & $4.7 \%$ \\
\hline
\end{tabular}

Moreover, two chert blade segments with trapezoidal cross section were found at KS A. A proximal segment with plain butt and small but not pronounced bulb with lipping, and parallel dorsal ridges indicates production by pressure technique. A second distal fragment with a width of $25.0 \mathrm{~mm}$ well matches the dimensions of so-called Canaanaen blades, although the available information (due to the missing butt) is not sufficient for the identification of the related technological blade tradition (for Canaanaen blades and related technologies $c f$. Chabot \& Pelegrin 2012: 190-196; Rosen 1997: 44-60, 2018; Schmidt 1996: 53-55; Thomalsky 2017).

There is some difference in the distribution of blade technologies among the assemblages. While the obsidian blade and bladelets (both pressure and percussion) were predominantly found at KS C and KS D, these techniques are not in evidence at KS A and KS E. The two chert blade segments were both found at KS A.

\subsection{Blank consumption and tool production}

Most of the obsidian tools found at Karmir Sar are characterized by very irregular retouches which were often created by use (Table 7). Many tools obviously served various functions, as is implicated by multiple working edges with different kinds of modifications or edge damages. This particularly concerns the retouched flake category, which is the most frequent tool class (38.7\%). The second most attested tool class is pièces esquillées $(18.7 \%$, Figure 5j, 6n-q), followed by scraping tools (10.3\%, Figure 5i, 6r-s, 7q) and drilling tools (9.0\%, Figure 5f-h, 6l-m, 7k-l). Notches and blade or bladelet tools (Figure 5c-d, 6a-k, 7c-j) each constitute around $4 \%$. Other tool classes are represented in small numbers, i.e. less than 2\%. Among them are denticulates (Figure 5e), burins or burin spalls (Figure 6a, i), bifacial implements (Figure 7m, n, p) and one arrowhead (Figure 7o).

There are some obvious differences in the composition of the four samples, which most likely have chronological implications. Backed bladelets are missing at KS A and KS E, where blade or bladelet tools generally are rare. Chert blade segments have been found at KS A and are missing among the other assemblages. Bifacial implements are in evidence at KS D and KS E. The only projectile known so far from Karmir Sar was found at KS E. All other tool classes are remarkably similar, although sometimes differences in quantities occur (e.g., higher numbers of retouched flakes and lower numbers of pièces esquillées in KS A). 


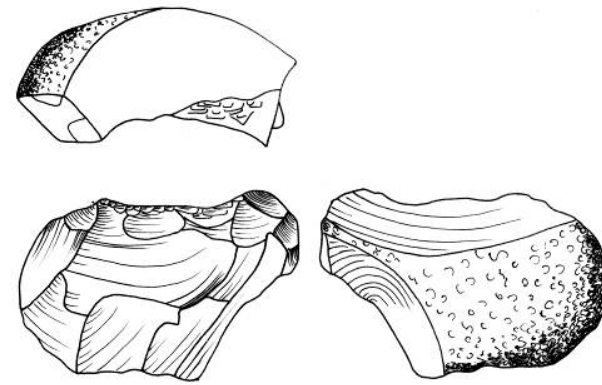

a (A102.3.2)
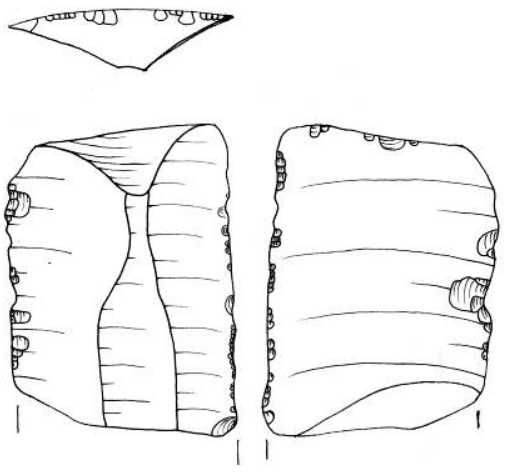

c (A99.5)
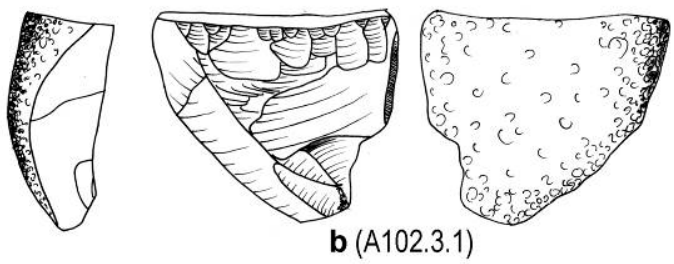

b (A102.3.1)

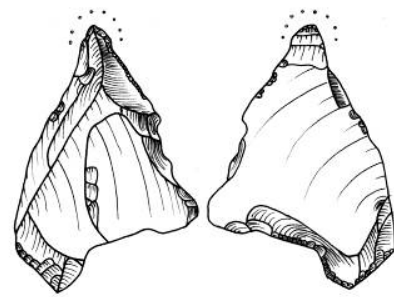

$\mathbf{f}(\mathrm{A} 83.9 .1)$

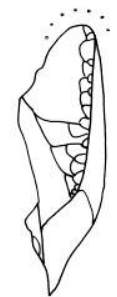

V
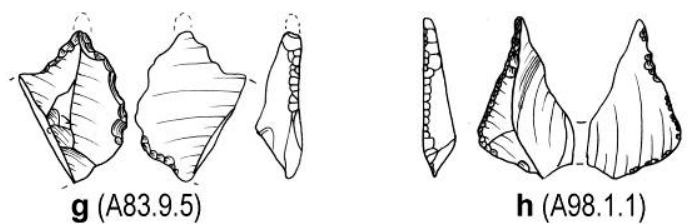

h (A98.1.1)

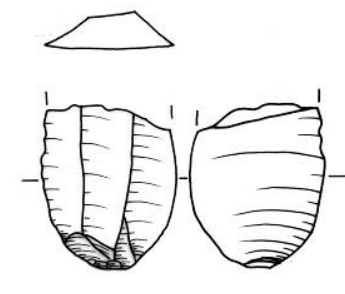

d (A111.2)

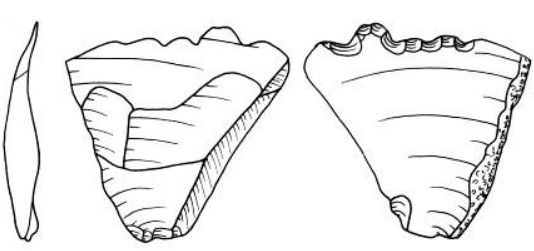

e (A106.2.2)

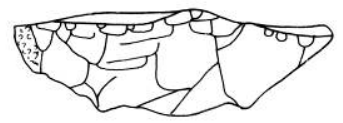

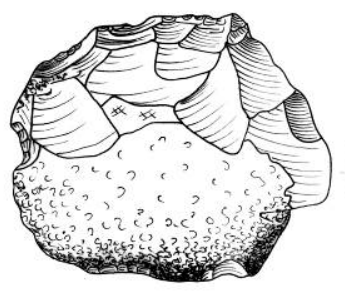

i (A94.7.1)

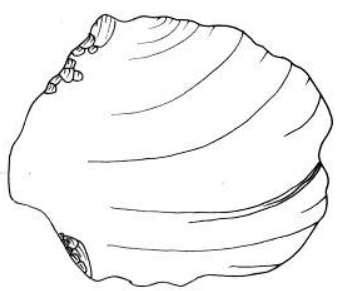

1)

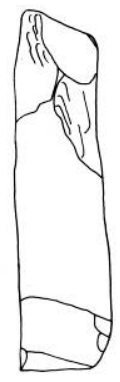

Figure 5. Lithic artefacts from KS A: a-b: flake cores; c-d: chert blade segments; e: denticulated flake; f: drill; gh: microborer; i: scraping tool; j: piéce esquillée; chert (c-d) and obsidian (a-b, e-j) (drawings by C. Purschwitz). 

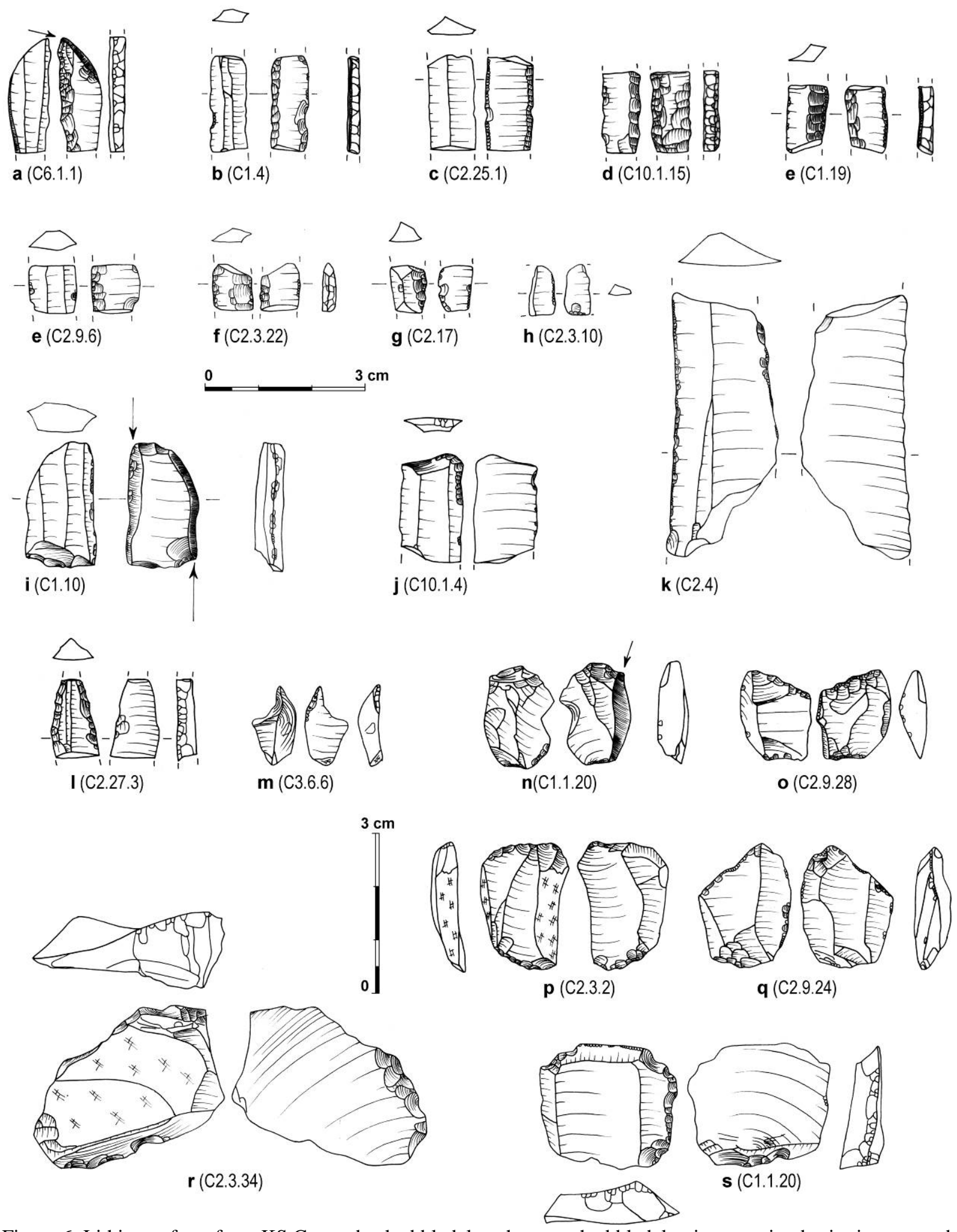

Figure 6. Lithic artefacts from KS C: a-g: backed bladelets; h: retouched bladelet; i: truncation burin; j: truncated blade; k: retouched blade; l: drill; m: microborer; n-q: piéces esquillées; r-s: scraping tools; all obsidian (drawings by C. Purschwitz). 

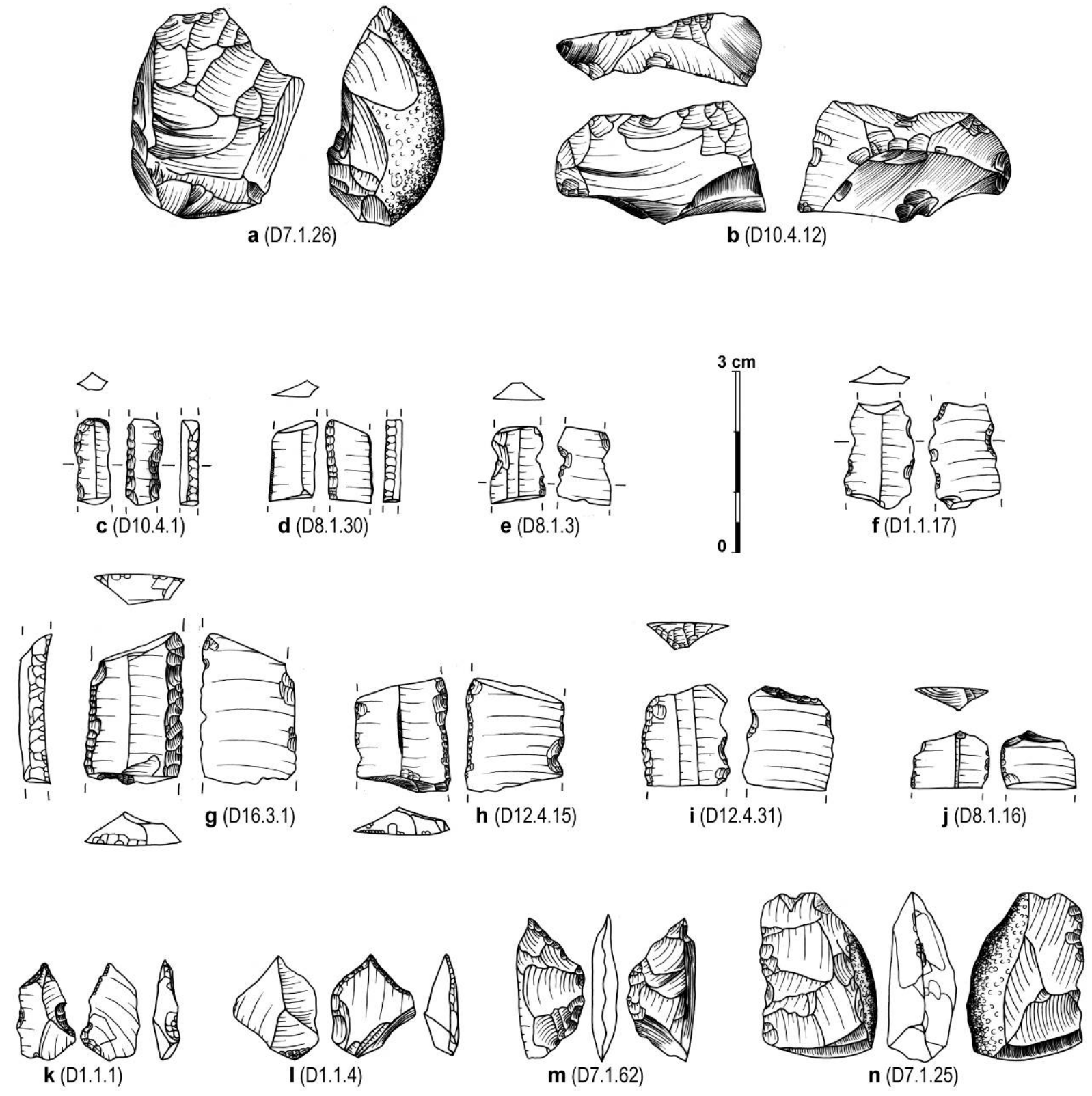

0

m (D7.1.62)

n (D7.1.25)

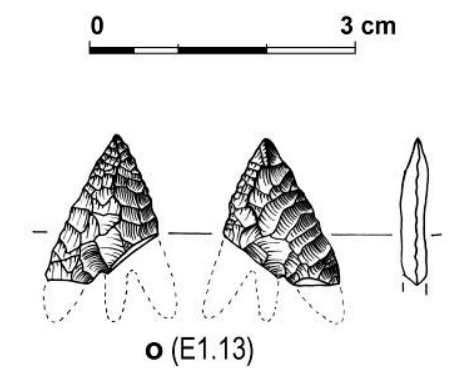

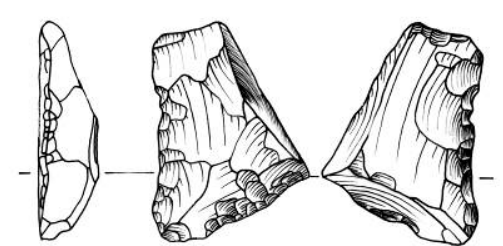

$\mathbf{p}(\mathrm{E} 1.5 .3)$

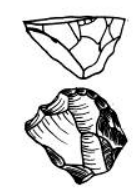

$\mathbf{q}(\mathrm{E} .5 .7)$

Figure 7. Lithic artefacts from KS D (a-n) and KS E (o-q): a-b: flake cores; c-d: backed bladelets; e-f: retouched bladelets; g-j: truncated blades; k-l: microborer; m-n, p: bifacial implements; o: arrowhead; q: thumbnail scraper; all obsidian (drawings by C. Purschwitz). 
Table 7. Breakdown of tools at Karmir Sar.

\begin{tabular}{l|cc|cc|cc|cc|cc}
\hline & \multicolumn{2}{|c|}{ KS A } & \multicolumn{2}{c|}{ KS C } & \multicolumn{2}{c|}{ KS D } & \multicolumn{2}{c|}{ KS E } & \multicolumn{2}{c}{ Total } \\
& $\mathrm{n}$ & $\%$ & $\mathrm{n}$ & $\%$ & $\mathrm{n}$ & $\%$ & $\mathrm{n}$ & $\%$ & $\mathrm{n}$ & $\%$ \\
\hline Projectiles & & & & & & & 1 & 9.1 & 1 & 0.3 \\
Backed and retouched blades & 3 & 3.0 & 2 & 1.8 & 5 & 6.9 & & & 10 & 3.4 \\
Bladelet tools & & & 9 & 8.0 & 3 & 4.2 & & & 12 & 4.1 \\
Drilling tools & 9 & 9.0 & 9 & 8.0 & 9 & 12.5 & & & 27 & 9.2 \\
Burins & 1 & 1.0 & 1 & 0.9 & & & & & 2 & 0.7 \\
Bifacial knives & & & & & 2 & 2.8 & 1 & 9.1 & 3 & 1.0 \\
Scrapers & 12 & 12.0 & 10 & 8.9 & 8 & 11.1 & 1 & 9.1 & 31 & 10.5 \\
Notches & 2 & 2.0 & 5 & 4.5 & 5 & 6.9 & & & 12 & 4.1 \\
Denticulates & 2 & 2.0 & 2 & 1.8 & 1 & 1.4 & & & 5 & 1.7 \\
Retouched flakes & 49 & 49.0 & 40 & 35.7 & 21 & 29.2 & 4 & 36.4 & 114 & 38.6 \\
Heavy-duty tools & 1 & 1.0 & 1 & 0.9 & & & & & 2 & 0.7 \\
Pièces esquillées & 15 & 15.0 & 23 & 20.5 & 14 & 19.4 & 1 & 9.1 & 53 & 18.0 \\
Hammerstones & & & & & 1 & 1.4 & & & 1 & 0.3 \\
Undetermined & 6 & 6.0 & 10 & 8.9 & 3 & 4.2 & 3 & 27.3 & 22 & 7.5 \\
\hline Tools & $\mathbf{1 0 0}$ & $\mathbf{1 0 0}$ & $\mathbf{1 1 2}$ & $\mathbf{1 0 0}$ & $\mathbf{7 2}$ & $\mathbf{1 0 0}$ & $\mathbf{1 1}$ & $\mathbf{1 0 0}$ & $\mathbf{2 9 5}$ & $\mathbf{1 0 0}$ \\
\hline
\end{tabular}

\subsubsection{Blank selection}

Flakes and to a lesser extent flakelets were the predominant blanks, and form $45.9 \%$ to $59 \%$ of the tool blanks (Figure 8). Surprisingly, a quite common blank category is debris, which often was used for pièces esquillées. Imported blade or bladelet segments are of minor importance and contribute between $4 \%$ to $14.5 \%$ of the blank supply.

\subsubsection{Tool production}

The irregular retouches of tools and the preferred use of on-site knapped flakes suggests that most flake tools were produced on-site, probably in an ad hoc environment of tool production and use, according to spontaneous daily demands. It appears quite likely that some of the small knapping waste (i.e. chips) was the result of tool production rather than of core reduction. This is the more likely, as platform preparation was hardly applied within the flake core reduction process.

As already mentioned there is no evidence of blade or bladelet tool production at Karmir Sar. We therefore consider the blade and bladelet implements to have been brought to the site as already retouched tools. The same for the isolated projectile point, as there is no other evidence of pressure retouch among the samples.

\section{Discussion: dating evidence and socioeconomic context}

The Karmir Sar obsidian industry is mainly composed of simple flakes and flake tools which have been produced and used in an ad hoc tool environment. The composition and quantity of primary products and the abundance of microdebris (i.e. chips, flakelets, debris), clearly demonstrate that flake core reduction and flake tool production was practiced on-site.

From a chronological point of view, flake artefacts are very undiagnostic and such ad hoc tool industries were characteristic of several periods, probably starting with the Neolithic to Chalcolithic transition (e.g., Badalyan et al. 2004b; Chataigner et al. 2014; Kirugadze 2000; Rosen 1997; Sagona et al. 1998). Moreover, the majority of the obsidian 
artefacts are not connected to the construction of the stone structures, and it is therefore likely that the samples represent multi-use episodes over more than one period.

\section{KS A}
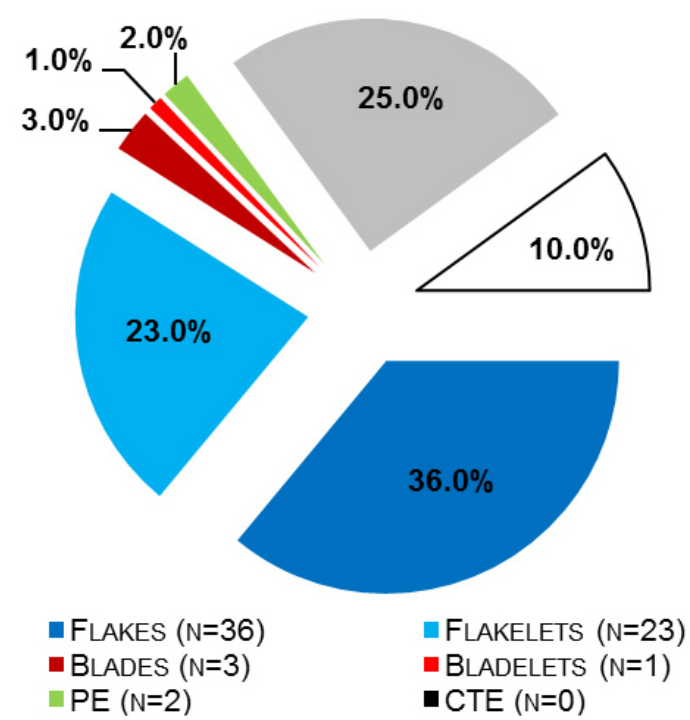

KS C
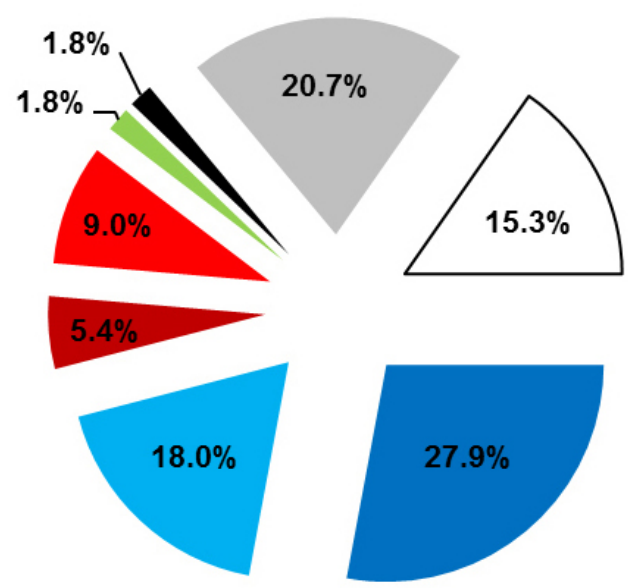

FLAKES ( $\mathrm{N}=31)$

- BLADES ( $\mathrm{N}=6)$

PE (N=2)

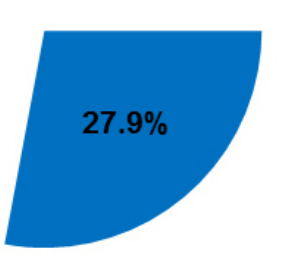

FLAKELETS $(\mathrm{N}=20)$

BLADELETS $(\mathrm{N}=10)$

- CTE ( $\mathrm{N}=2)$
BLADELETS $(\mathrm{N}=1)$

KS D
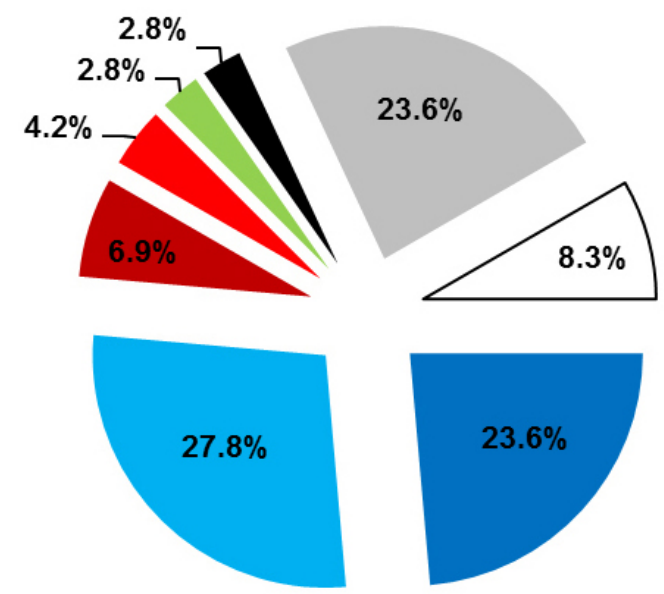

- FLAKES ( $\mathrm{N}=17)$

- BLADES ( $\mathrm{N}=5)$ PE $(\mathrm{N}=2)$
FLAKELETS $(\mathrm{N}=20)$
BLADELETS $(\mathrm{N}=3)$
- CTE $(\mathrm{N}=2)$

Figure 8. Blank-tool distribution at KS A, KS C and KS D.

However, there are a few chronologically sensitive tool classes, such as arrowheads, backed bladelet and truncated blade segments, which provide additional information on the occupation periods - such as the Chalcolithic or perhaps the Early Bronze Age (EBA) - that are not or are poorly attested by other artefact evidence (i.e. pottery).

The most diagnostic tool type is backed implements, often made on pressure blades or bladelets. All bladelet implements show a characteristic backing, which occasionally has been carried out bifacially. Although our dating evidence on backed bladelets is quite limited, similar implements are reported from Late Neolithic to late Chalcolithic sites such as Aknalitch, Sioni, and Barepat-1 cave (Arimura et al. 2014: fig. 3.8; Kirugadze \& Menabde 2004: fig. 30.3; Muradyan 2014: fig. 10.5-7, fig. 12.13). Bladelet tools, and tools with bifacial 
backing are reported from Hovk-1 and Hovk-3 rock shelters (Arimura et al. 2014: fig. 7-8) as well as Sioni (Kirugadze \& Menabde 2004: fig. 30.3). According to Thomalsky (Thomalsky in Marro et al. 2011, Thomalsky 2017) bladelets tools and backed blades are a common element among the Chalcolithic obsidian industry of Ovçular Tepe at Nakhchivan (late 5th to early 4th millennium BCE). The low number of blades or bladelets and the abundance of flake and flakelets within the lithic assemblages of KS C and KS D may indicate a rather late position for this blade(let) industry within the Chalcolithic period, perhaps even including the Chalcolithic-EBA-transition (cf. Kirugadze 2000).

A broken obsidian projectile from KS E can be reconstructed as a winged and tanged arrowhead which is shaped by very regular, invasive bifacial retouches via pressure technique (Figure 80). In the well stratified site of Norşuntepe (Upper Euphrates), small winged and tanged arrowheads first occur in the later Chalcolithic and continue into the EBA-Period. According to the Norşuntepe sequence there is a clear tendency from simple edge-retouched flake or blade-based points in Chalcolithic layers, to a bifacial, invasive and very regular retouch for winged and tanged arrowheads (types "Lidar" and "Tepecik") in the early EBA layers (cf. Schmidt 1996: 74-77). There are only few winged and tanged points published from Chalcolithic sites of the southern Caucasus, which include finds from the sites Aknalitch (Muradyan 2014: fig. 12.14), Mushakan 4 (Muradyan 2014: footnote 5), and Ovçular Tepe (Marro et al. 2011: pl. XI.8). The two illustrated points from Aknalitch and Ovçular Tepe show small points on flakes with non-invasive edge retouches, which well fit the Chalcolithic winged and tanged arrowheads of Norşuntepe. The point which we found at KS E more resembles the "Lidar" or "Tepecik" types of the Upper Euphrates region for which an EBA date is suggested by us based on the Norşuntepe sequence (cf. Schmidt 1996: 75-76; $c f$. also Sagona et al. 1998: fig. 14.7-8 for similar points from EBA-layers at Sos Höyük). In the southern Caucasus winged and tanged points with regular, invasive bifacial retouches are frequently found at the settlement sites of the Kura Araxes horizon (c. 3500-2500 or 2200 BCE, cf. Palumbi \& Chataigner 2014; Palumbi 2016), such as Shengavit or Karnut I (e.g., Badalyan \& Avetisan 2007: 138-149; Kushnarova 1997: fig. 21.20; Simonyan 2015), and are also reported from EBA-burials (e.g., Rova 2012, 2014: 62). However, except for this projectile point there is no hard evidence of EBA occupation at Karmir Sar, although some bifacial obsidian implements might be related to 3rd millennium Caucasian (chert) sickles.

The presence of two pressure blade segments on chert (Figure 6c-d) and the absence of obsidian blade or bladelets at KS A may be noteworthy. Although there is a long tradition of pressure blade production in the southern Caucasus ( $c f$. Chabot \& Pelegrin 2012; Thomalsky 2017), blade production on chert or flint appears to be rather exceptional for the Neolithic or Chalcolithic sites of the Aragat mountain area and the Ararat plain (Arimura et al. 2009, 2012; Badalyan et al. 2010: 196; cf. also Gatsov \& Nedelcheva 2008 for Aruchlo I, and Thomalsky 2017: 83-84 for Ovçular Tepe). However, chert and flint are commonly used for (pressure) blade production in Mesopotamia, the Upper Euphrates region, or the Levant, where so-called Canaanaen blade technologies flourished from the late 4th until the end of the 3rd millennium BCE (Chabot \& Pelegrin 2012; Hartenberger et al. 2000; Rosen 1997: 106111, 2018; Schmidt 1996: 53-64; Thomalsky 2012a: 282-292, 2012b, 2017). Of interest here might be the recent findings from Ovçular Tepe where chert processing (including blades production) appears to be associated with EBA-layers and not with Chalcolithic ones (Thomalsky 2017: 83). However, the available data on chert blades at Karmir Sar (as well as on Caucasian chert blades in general) is not sufficient for making any conclusions on origin or technological tradition. Nevertheless, our comprehensive data from KS A let us to expect a late $4^{\text {th }}$ to $3^{\text {rd }}$ millennium association of these chert blades as being most likely, although we cannot exclude a Neolithic or Chalcolithic origin. 
Isolating the MBA component of lithic industries is a difficult enterprise. For the southern Caucasus, there are only very few tool types known which can be confidently dated to the MBA period. Most diagnostic are small winged pressure retouched obsidian points with hollow base ("Bedeni" or "Trialeti"-points, although such points first occur during the late 3rd millennium BCE and continue until the end of the 2nd millennium, $c f$. Schmidt 1996: 79-81). The overall "invisibility" of post-EBA lithics in the Caucasus and the entire Fertile Crescent is also caused by a general decline of lithic technology and the abandonment of formal blade technologies (cf. Rosen 1997). However, the lack of evidence of diagnostic MBA lithics at Karmir Sar does not preclude their existence. The almost total absence of projectiles (including characteristic transverse arrowheads in the Chalcolithic period) is easily explained by the environmental settings of the Karmir Sar meadow which was used as summer pasture and which has a very low potential for hunting. In contrast, the stratigraphic position of abundant lithic artefacts within and upon the cromlechs in KS A clearly shows that lithic artefacts constantly were deposited there during MBA, and perhaps even during later periods. Though undiagnostic obsidian artefacts are rarely reported from post-Chalcolithic sites, there appears to be a common association between chipped lithic artefacts and Bronze to Iron Age kurgans, cromlechs or stone barrows (cf. Badalyan \& Avetisyan 2007; Muradyan 2014: footnote 4; Shanshavili 2004; Shatberashvili et al. 2010; Simonyan 1988; $c f$. also Chataigner \& Gratuze 2014). Some see this association as part of a complex burial ritual (e.g., Shanshavili 2004; Simonyan 1988) but the composition of the obsidian assemblages from KS A show complete reduction sequences with all size classes presented (including abundant microdebris), and clearly demonstrate the on-site processing of obsidian including the production and use of tools. We suggest that the majority of (if not all) obsidian artefacts are not related to the cromlechs or stone structures but represent relicts from multiple later visits and knapping events. The concentration of obsidians around these stone structures might simply be caused by the visibility of the stone monuments within the grass landscape. They may have functioned as focal points which attract people, as these stone structures provide convenient sitting and working platforms within a wet grass landscape. The repeated stays of humans in later periods is well illustrated by the modification of a fallen vishap face into a game board in KS C (Figure 3)

The ephemeral character of occupation and the resulting lack of clear stratigraphic horizons at Karmir Sar (and at many other Caucasian open-air sites) does not allows for a fine-scaled lithic chronology, or for the definition of single phase or single period lithic industries. Nevertheless, the presence of certain technological traits and traditions, or specific tool types at some spots and their absence at others, clearly indicates some chronological differences in use. Due to the lithic decline we are more able to make conclusions about the absence or presence of Chalcolithic artefacts than on MBA or LBA lithic production. However, given the combined data on ${ }^{14} \mathrm{C}$-dates, pottery and diagnostic chipped lithic artefacts, we have strong evidence to support chalcolithic occupational episodes at KS C and KS D. There might be a late 6th millennium occupation at KS A (as indicated by a ${ }^{14} \mathrm{C}$-date), though we lack clear artefact evidence from this period so far. In contrast, the KS A assemblage appears to be largely from an MBA date or younger. The very small assemblage of KS E is difficult to date. The stone structure is of Medieval age, although there might be an earlier occupation as indicated by the late Chalcolithic to EBA projectile point.

The socioeconomic settings that can be drawn from the Karmir Sar lithics well matches those expected from semi-mobile herders. Although some mixing between Chalcolithic and MBA material is obvious, the Karmir Sar assemblages are very similar and mainly differ by the presence or absence of an off-site produced blade and bladelet component. A flexible tool kit is based on a simple, but very efficient flake technology which can be easily and spontaneously produced by the herders themselves, according to daily demands. This kind of 
ad hoc flake and flake tool production can be practiced by every community member and done almost everywhere (including remote areas such as Karmir Sar) without being dependent on specialized blade producers or traders. The only strategic planning concerns raw material procurement, as neither chert nor obsidian sources are available at Karmir Sar. The raw material was predominantly procured from riverine deposits, as evidenced by high numbers of battered and rolled surfaces, and pebbles of small sizes. We suspect that embedded procurement strategies prevailed, and obsidian nodules were collected by the herders while watering their stock at the rivers. Probably, few obsidian nodules of flake cores would have been sufficient to cover the demand for tools during the seasonal stay at Karmir Sar. Evidence of exchange is scanty and may include the blades and bladelet tools as there is no evidence of on-site practice of blade or bladelet technologies at Karmir Sar.

\section{Conclusions}

The obsidian industries of Karmir Sar are characterized by an ad hoc tool production environment, which well matches the needs and demands of semi-mobile herders who visited the highland meadow with their livestock during the summer months. They produced their tools on-site, and according to daily demand by simple flake core technology which allowed for a very flexible, spontaneous blank and tool production without being dependent on specialized blade producers or traders. The majority of the raw material appears to be procured directly by the herders from the riverbed of the Ararat plain, as is indicated by a high ratio of battered and rolled surfaces. We suspect that embedded raw material procurement, e.g., collecting obsidian pebbles from rivers while watering the stock, represents the predominant procurement mode. The raw material later was brought as (pre-shaped) flake cores to Karmir Sar, where it was processed into desired flake tools.

The age of the majority of the Karmir Sar flake industry is difficult to estimate, since most of the artefacts are (chronologically) undiagnostic. The situation is becoming quite complicated, as there is plenty of evidence of multiple use episodes at Karmir Sar, starting in the Chalcolithic Period and continuing (with some gaps) until modern times. Nevertheless, the presence of specific tool types and technologies among some of the samples and their absence at others, as well as differences and changes in raw material procurement, may contribute to a better understanding of the complex occupation history of the Karmir Sar meadow.

\section{Acknowledgements}

The excavation at Karmir Sar and the obsidian study was carried out within the project “The Armenian Dragon Stones" funded by the Thyssen-Foundation (2014-2017). I would like to thank Alessandra Gilibert, Pavol Hnila, and Arsen Bobokhyan for providing me the opportunity to study the Karmir Sar obsidian artefacts, for their support, and for providing me with unpublished data, as well as their helpful comments on the drafts of this paper. I thank Judith Thomalsky and Makuto Arimura for sharing their ideas on the Karmir Sar obsidian industry. I also thank the reviewers for their very helpful comments and suggestions. The English was edited by Brian Agro.

\section{References}

Arimura, M., Chataigner, C. \& Gasparyan, B. 2009, Kmlo 2. An Early Holocene Site in Armenia. Neo-Lithics, 2009(2): 17-19. URL: http://www.exoriente.org/docs/00072.pdf 
Arimura, M., Gasparyan, B., Nahapetyan, S. \& Pinhasi, R. 2014, Forest Exploitation during the Holocene in the Aghstev Valley, Northeast Armenia. In: Stone Age of Armenia. A Guide-book to the Stone Age Archaeology in the Republic of Armenia (Gasparyan, B. \& Arimura, M., Eds.), Center for Cultural Resource Studies, Kanazawa University, Kanazawa: p. 261-282.

Badalyan, R.S. \& Avetisyan, P.S. 2007, Bronze and Early Iron Age Archaeological Sites in Armenia. I. Mt. Aragats and its Surrounding Region. BAR International Series Vol. 1697, Archaeopress, Oxford, 319 p.

Badalyan, R.S., Chataigner, C. \& Kohl, P.L. 2004a, Trans-Caucasian Obsidian: The Exploitation of the Sources and their Distribution. In: A View from the Highlands. Archaeological Studies in Honour of Charles Burney (Sagona A., Ed.), Ancient Near Eastern Studies Supplement Series Vol. 12, Peeters, Leuven: p. 438-465.

Badalyan, R.S., Lombard, P., Chataigner, C. \& Avetisyan, P. 2004b, The Neolithic and Chalcolithic Phases in the Ararat Plain (Armenia): The View from Aratashen. In: A View from the Highlands. Archaeological Studies in Honour of Charles Burney (Sagona A., Ed.), Ancient Near Eastern Studies Supplement Series Vol. 12, Peeters, Leuven: p. 399-420.

Badalyan, R.S., Harutyunyan, A.A., Chaataigner, C., Le Mort, F., Chabot, C., Brochier, J.-E., Balasescu, A., Radu, V. \& Hovsepyan, R. 2010, The Settlement of AknashenKhatunarkh, A Neolithic Site in the Ararat Plain (Armenia): Excavation Results 20042009. TÜBA-AR, 13: 187-220.

Barge, O. \& Chataigner, C. 2003, The procurement of obsidian: factors influencing the choice of deposits. Journal of Non-Crystalline Solids, 323 (1-3): 172-179. doi:10.1016/s00223093(03)00301-6

Bobokhyan, A., Gilibert, A. \& Hnila, P. 2012, Vishaps of the Geghama Mountains. New discoveries and propedeutics to a history of research. ARAMAZD. Armenian Journal of Near Eastern Studies, 7(2): 7-27. URL: http://hdl.handle.net/10278/3665418

Bobokhyan, A., Gilibert, A. \& Hnila, P 2018, Karmir Sar. New evidence on dragon stones and ritual landscapes on Mount Aragats, Armenia. In: Context and Connection. Essays on the Archaeology of the Ancient Near East in Honour of Antonio Sagona (A. Batmaz, A., Bedianishvili, G., Michalewicz, A. \& Robinson, A., Eds.), Orientalia Lovaniensia Analecta, Peeters, Leuven: p. 255-270.

Braswell, G.E. 1996, Obsidian hydration dating. In: The Oxford Companion to Archaeology (Fagan, B.M., Ed.), Oxford University Press, Oxford: p. 537.

Chabot, J. \& J. Pelegrin 2012, Two Examples of Pressure Blade Production with a Lever: Recent Research from the Southern Caucasus (Armenia) and Northern Mesopotamia (Syria, Iraq). In: The Emergence of Pressure Blade Making: From Origin to Modern Experimentation (Desrosiers, P., Ed.), Springer Verlag, Heidelberg \& Berlin: p. 181-19. doi:10.1007/978-1-4614-2003-3_6

Chataigner, C. \& Gratuze, B. 2014, New data on the exploitation of obsidian in the southern Caucasus (Armenia, Georgia) and eastern Turkey, part 2: Obsidian procurement from the Upper Palaeolithic to the Late Bronze Age. Archaeometry, 56: 48-69. doi:10.1111/arcm.12007

Chataigner C., Badalyan R., Arimura M., 2014. The Neolithic of the Caucasus. Oxford Handbooks Online: 34 p. doi:10.1093/oxfordhb/9780199935413.013.13 
Frahm, E., 2010, The Bronze-Age Obsidian Industry at Tell Mozan (Ancient Urkesh) Syria. Ph.D. thesis at the Department of Anthropology, University of Minnesota, Minneapolis, 1019 p. Retrieved from the University of Minnesota's Digital Conservancy. URL: http://purl.umn.edu/99753

Frahm, E., Schmidt, B.A., Gasparyan, B., Yeritsyan, B., Karapetian, S., Meliksetian, K. \& Adler, D.S. 2014, Ten seconds in the field: rapid Armenian obsidian sourcing with portable XRF to inform excavations and surveys. Journal of Archaeological Science, 41: 333-348. doi:10.1016/j.jas.2013.08.012

Gasparyan, B. \& Arimura, M., (Eds.) 2014, Stone Age of Armenia. A Guide-book to the Stone Age Archaeology in the Republic of Armenia. Centre for Cultural Resource Studies, Kanazawa University, Kanazawa, 371 p.

Gatsov, I. \& P. Nedelcheva 2008, Lithic assemblages from Aruchlo I (Georgia). In: Наукові праиі Миколаївського державного гуманітарного університету Історичні науки, Historical Sciences, Sir: p. 38-43.

Gilibert, A. 2015, The Armenian dragon stones and a seal impression from Acemhöyük. In: The Vishap Stone Stelae (Petrosyan, A. \& Bobokhyan, A., Eds.), NASRA “Gitutyun” Publishing houses, Yerevan: p. 205-210.

Gilibert, A. 2017, Nella terra dei draghi giganti. Archeo, 394: 40-57. (In Italian) ("In the Land of the Dragon Giants”)

Gilibert, A., Bobokhyan, A. \& Hnila, P. 2012, Dragon stones in context. The discovery of high-altitude burial grounds with sculpted stelae in the Armenian Mountains. Mitteilungen der Deutschen Orient-Gesellschaft zu Berlin, 144: 93-132.

Gilibert, A., Bobokhyan, A. \& Hnila, P. 2013, Die armenischen višap. In: Archäologie in Armenien II. Ergebnisse der Kooperationsprojekte 2010 - Berichte zu den Kooprationsprojekten 2011 und 2012 sowie ausgewählte Einzelstudien (Meller, H. \& Avetisyan, Eds.), Veröffentlichungen des Landesamtes für Archäologie in SachsenAnhalt Vol. 67, Verlag Beier \& Beran, Halle, Saale: p. 195-205. (in German) ("The armenian vishaps”)

Greenfield, H.J. 2013, The fall of the house of flint: A zoological perspective on the decline of chipped stone tools for butchering animals in the Bronze and Iron Ages of the Southern Levant. Lithic Technology, 38(3): 161-178. doi:10.1179/0197726113Z.00000000019

Hnila, P., Gilibert, A., Bobokhyan, A, in press, Prehistoric sacred landscapes in the mountains of East Turkey and the South Caucasus: the case of the vishap stelae. In: Natur und Kult in Anatolien. Viertes wissenschaftliches Netzwerk der Abteilung Istanbul des Deutschen Archäologischen Instituts (Engels, B., Huy, S. \& Steitler, C., Eds.), Manuscript submitted and accepted. $23 \mathrm{p}$.

Hartenberger, B., Rosen, S.A. \& Matney, T. 2000, The Early Bronze Age blade workshop at Titris Höyük. Near Eastern Archaeology, 63(1): 51-58. doi:10.2307/3210808 
Kiguradze, T. 2000, The Chalcolithic - Early Bronze Age transition in the eastern Caucasus. In: Chronologies des pays du Caucase et de l'Euphrate aux IVe-IIIe millénaires. From the Euphrates to the Caucasus: Chronologies for the $4^{\text {th }}-3^{\text {rd }}$ millennium B.C. Vom Euphrat in den Kaukasus: Vergleichende Chronologie des 4. und 3. Jahrtausends v. Chr. Actes du Colloque d'Istanbul, 16-19 décembre 1998 (Hauptmann, H. \& Marro, C., Eds.), Varia Anatolica Vol. 11, Institut français d'études anatoliennes d'Istanbul, Paris: p. 321-328. URL: http://www.persee.fr/doc/anatv_1013-9559_2000_act_11_1_937

Kirugadze, T. \& Menabde, M. 2004, The Neolithic of Georgia. In: A View from the Highlands. Archaeological Studies in Honour of Charles Burney (Sagona A., Ed.), Ancient Near Eastern Studies Supplement Series Vol. 12, Peeters, Leuven: p. 539-556.

Kobayashi, K. 2007, An obsidian refitting from Sos Höyük, Eastern Turkey. Near Eastern Archaeology, 44: 141-154. doi:10.2143/ANES.44.0.2022829

Kushnareva, K.Kh. 1997, The Southern Caucasus in Prehistory. Stages of Cultural and Socioeconomic Development from the Eight to the Second Millennium B.C., (Translated by H.N. Michael), Museum of Archaeology and Anthropology Philadelphia Vol. 99, The University Museum, University of Philadelphia, Philadelphia, 279 p.

Marro, C., Bakhshaliyev, V. \& Ashurov, S. 2011, Excavations at Ovcular Tepesi (Nakhchivan, Azerbaijan). Second Preliminary Report: The 2009-2010 Seasons. Anatolia Antiqua, 19: 53-100. doi:10.3406/anata.2011.1089

Muradyan, F. with contributions by Zardaryan, D., Gasparyan, B. \& Aghikyan, L. 2014, Discovery of the First Chalcolithic Burial Mounds in the Republic of Armenia. In: Stone Age of Armenia. A Guide-book to the Stone Age Archaeology in the Republic of Armenia (Gasparyan, B. \& Arimura, M., Eds.), Center for Cultural Resource Studies, Kanazawa University, Kanazawa: p. 339-364.

Niskhiaki, Y. 2014, Dating simple flakes: Early Bronze Age flake production technology on the Middle Euphrates Steppe, Syria. Journal of Lithic Studies, 1(1): 197-212. doi:10.2218/jls.v1i1.781

von der Osten, H., Hnila, P., Gilibert, A. \& Bobokhyan, A. in press. Integrated archaeogeophysical survey on volcanic terrain: The case of Karmir Sar on Mount Aragats (Republic of Armenia). TÜBA-AR, Manuscript submitted and accepted. 7 p.

Palumbi, G. 2016, The Early Bronze Age of the Southern Caucasus. In: Oxford Handbooks Online. doi:10.1093/oxfordhb/9780199935413.013.14

Palumbi, G. \& Chataigner, Ch. 2014, The Kura-Araxes Culture from the Caucasus to Iran, Anatolia and the Levant: Between Unity and Diversity. A Synthesis. Paléorient, 40(2): 247-260. doi:10.3406/paleo.2014.5645

Petrosyan, A. \& Bobokhyan, A. (Eds.) 2015, The Vishap Stone Stelae, NASRA “Gitutyun” Publishing houses, Yerevan, $420 \mathrm{p}$.

Purschwitz, C. 2017, Die lithische Ökonomie von Feuerstein im Frühneolithikum der Größeren Petra Region. Studies in Early Near Eastern Production, Subsistence, and Environment Vol. 19. ex oriente, Berlin, 620 p. (in German) ("The Lithic Economy of Flint in the Early Neolithic Period of the Greater Petra Region”) 
Purschwitz, C. in press, Socio-economic Changes in Flint Production and Consumption in the PPNB Period of the Greater Petra Region, Southern Levant. In: Proceedings of the 8th Conference of Pre-Pottery Neolithic Chipped Stone and Ground Stone Industries of the Near East, Nicosia, November 23rd-27th 2016 (McCartney, C., Briois, F. \& Astruc, L., Eds.), Manuscript submitted and accepted. 17 p.

Quintero, L.A. 2010, Evolution of Lithic Economies in the Levantine Neolithic. Development and Demise of Naviform Core Technology as Seen from 'Ain Ghazal. Bibliotheca neolithica Asiae meridionalis et occidentalis, ex oriente, Berlin, 184 p.

Rova, E. 2012, Lithics and Other Small Finds. In: Khashuri Natsargora: The Early Bronze Age Graves (Puturidze, M. \& Rova, E., Eds.), Subartu Vol. 30, Brepols Publishers, Turnhout: p. 53-58.

Rova, E. 2014, The Kura-Araxes Culture in the Shida Kartli region of Georgia: An overview. Paléorient, 40(2): 47-69. doi:10.3406/paleo.2014.5635

Rosen, S.A. 1997, Lithics after the Stone Age. A Handbook of Stone Tools from the Levant. Altamira Press, Walnut Creek, 184 p.

Rosen, S.A. 2018, Canaanaen Blades. In: ARCANE Interregional II, Artefacts (Lebeau, M., Ed.), Brepols Publishers, Turnhout: p. 203-215.

Rosen, S.A. \& Vardi, K. 2014, Chipped Stone Assemblage from Tell Jemmeh. In: The Smithsonian Institution Excavation at Tell Jemmeh, Israel, 1970-1990. (Ben-Shlomo, D. \& Van Beek, G.W., Eds.), Smithsonian Contribution to Anthropology Vol. 50. Smithsonian Institution Scholarly Press, Washington: p. 987-1003.

Sagona, A., Erkmen, M., Sagona, C., McNiven, I. \& Howells, S., Excavations at Sos Höyük 1997: Fourth preliminary report. Anatolica, 24: 31-64. doi:10.2143/ana.24.0.2015476

Schiffer, M.B. 1987, Formation Processes of the Archaeological Record. University of New Mexico Press, Albuquerque, 428 p.

Schmidt, K. 1996, Norsuntepe. Kleinfunde I. Die lithische Industrie. Archaeologica Euphratica Vol. 1, Verlag Philipp von Zabern, Mainz, 145 p. (in German) ("Norsuntepe. Small Finds I. The Lithic Industry”)

Shanshashvili, N. 2004, The importance of obsidian in burial rites. doj8s6o, 13/14: 72.

Shatberashvili, Z., Shatberashvili, V. \& Nikolaishvili, V. 2011, Bronze Age Burials at Tqemlara. In: Rescue Archaeology in Georgia: The Baku-Tblisi-Ceyhan and South Caucasus Pipelines (Gramkrelidze, G., Erkomaishvili, N., Kvirkvelia, G., Narimanishvili, G., Sadradze, V., Tsereteli, M. \& Tskvitinidze, Z., Eds.), Georgian National Museum, Tblisi: p. 381-409.

Simonyan, H.E. 1988, Обсидиан и кремень' как атрибуты погребал'ного обряда. In: Вопросы изучения армянской народной культуры. Культура и язык, VIII Конференция молодых ученых (19-21, апреля 1988 r.), Тезисы докладов) (Kharatyan, Z.V. \& Petrosyan, H.L., Eds.),Armenian SSR Academy of Sciences Institute of Archaeology and Ethnography Press, Yerevan: p. 79-81. (in Russian) (“Obsidian and flint as attributes of burial ceremony”)

Simonyan, H.E. 2015, The Archaeological Site of Shengavit: An Ancient Town in the Armenian Highland. Fundamental Armenology, 2015(2): 148-183. URL: http://www.fundamentalarmenology.am/datas/pdfs/102.pdf 
Steadman, S.R., McMahon, G., Ross, J.C., Cassis, M., Geyer, J.D., Arbuckle, B. \& von Beyer, M., 2013, The 2009 and 2012 seasons of excavation at Cadir Höyük on the Anatolian north central plateau. Anatolica, 39: 113-167.

Thomalsky, J. 2012a, Lithische Industrien im vorderasiatischen und ägyptischen Raum. Untersuchungen zur Organisation lithischer Produktion vom späten 6. bis zum ausgehenden 4. Jt. v. Chr. Ph.D. dissertation thesis at the Institute of Prehistoric Archaeology, University of Tübingen, Universitätsbibliothek, Publikationssystem, Tübingen, 582 p. (in German) ("Lithic Industries of the Ancient Near East and Egypt. Investigation of Organization of Lithic Production from the late $6^{\text {th }}$ to the late $4^{\text {th }}$ millennium BC”) URL: http://hdl.handle/10900/47038

Thomalsky, J. 2012b, Lithic Industries of the Ubaid and Post-Ubaid Period in Northern Mesopotamia. In: After the Ubaid: Interpreting Change from the Caucasus to Mesopotamia at the Dawn of Urban Civilization (4500-3500 BC). Papers from The Post-Ubaid-Horizon in the Fertile Crescent and Beyond International Workshop held at Fosseuse, 29th June - 2st July 2009 (Marro, C., Ed.), Varia Anatolica Vol. 27, De Boccard Èdition - Diffusion, Paris: p. 417-439.

Thomalsky, J. 2017, Large Blade Technologies in the Southern Caucasus and in Northern Mesopotamia in the $6^{\text {th }}-4^{\text {th }}$ millennium BC. In: At the Northern Frontier of Near Eastern Archaeology. Recent Research on Caucasia and Anatolia in the Bronze Age (Rova, E. \& Tonussi, M., Eds.), Subartu Vol. 38, Brepols, Turnhout: p. 79-90. 